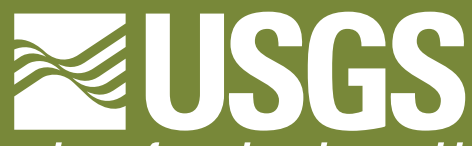

science for a changing world

Prepared in cooperation with the National Park Service

\title{
The Relative Importance of Oceanic Nutrient Inputs for Bass Harbor Marsh Estuary at Acadia National Park, Maine
}

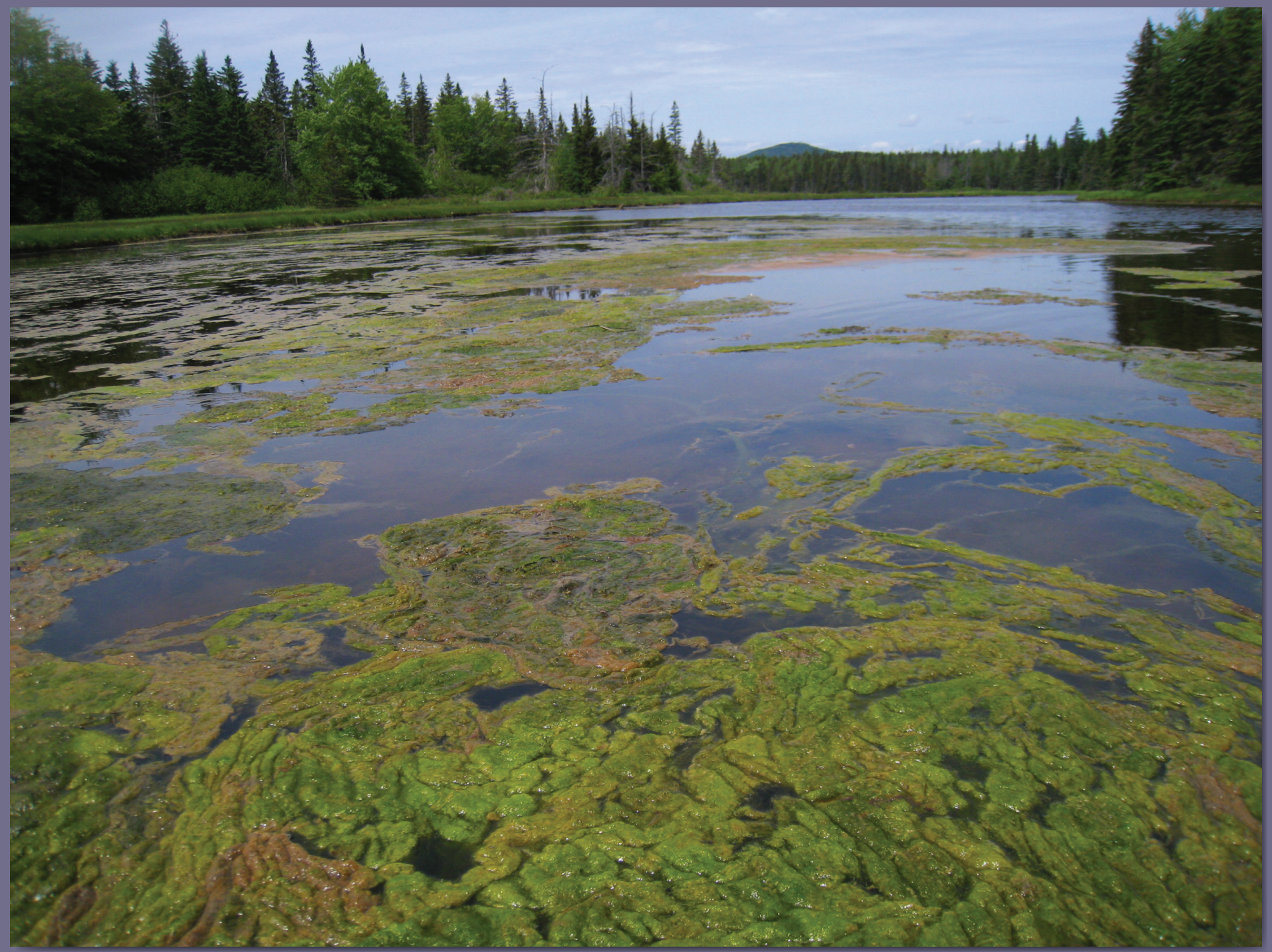

Scientific Investigations Report 2014-5123 
Front cover. Photograph of the Bass Harbor Marsh Estuary, Maine, on June 11, 2011, from a point near the center of the widest part of the estuary (approximate latitude $44^{\circ} 15^{\prime} 25^{\prime \prime}$ and longitude $-68^{\circ} 20^{\prime} 42^{\prime \prime}$ ) looking north. The water surface is largely covered with green macroalgae. Photograph courtesy of Charlie Jacoby, National Park Service. 


\section{The Relative Importance of Oceanic Nutrient Inputs for Bass Harbor Marsh Estuary at Acadia National Park, Maine}

By Thomas G. Huntington, Charles W. Culbertson, Christopher Fuller,

Patricia Glibert, and Luke Sturtevant

Prepared in cooperation with the National Park Service

Scientific Investigations Report 2014-5123 


\title{
U.S. Department of the Interior SALLY JEWELL, Secretary
}

\section{U.S. Geological Survey Suzette M. Kimball, Acting Director}

\author{
U.S. Geological Survey, Reston, Virginia: 2014
}

For more information on the USGS - the Federal source for science about the Earth, its natural and living resources, natural hazards, and the environment, visit http://www.usgs.gov or call 1-888-ASK-USGS.

For an overview of USGS information products, including maps, imagery, and publications, visit http://www.usgs.gov/pubprod/.

To order this and other USGS information products, visit http://store.usgs.gov/.

Any use of trade, firm, or product names is for descriptive purposes only and does not imply endorsement by the U.S. Government.

Although this information product, for the most part, is in the public domain, it also may contain copyrighted materials as noted in the text. Permission to reproduce copyrighted items must be secured from the copyright owner.

Suggested citation:

Huntington, T.G., Culbertson, C.W., Fuller, Christopher, Glibert, Patricia, and Sturtevant, Luke, 2014, The relative importance of oceanic nutrient inputs for Bass Harbor Marsh Estuary at Acadia National Park, Maine: U.S. Geological Survey Scientific Investigations Report 2014-5123, 19 p., http://dx.doi.org/10.3133/sir20145123. 


\section{Acknowledgements}

The authors are grateful for the support they received from several people that contributed to the successful completion of this study. David Manski and William Gawley at Acadia National Park provided logistical support and meteorological, hydrologic, and water-quality data for the study. Karen Anderson of the National Park Service provided historical aerial photographs that were used to assess estuary channel widening.

Nick Stasulis, Laura Flight, and Anthony Underwood at the U.S. Geological Survey installed and maintained the flow gaging station at the estuary outlet and assisted with quality assurance and processing of the continuously collected water temperature and specific conductance data. Nick Stasulis provided the technical expertise for design and implementation of the collection of bathymetric data and post-processing of these data so that they could be incorporated into a geographic information system. Charles Schalk, Greg Stewart, and Pam Lombard of the U.S. Geological Survey provided technical reviews that strengthened various sections of the report. Keith Robinson and Edward Stets of the U.S. Geological Survey provided technical reviews that improved the report. Laurel Larsen of the U.S. Geological Survey provided equipment and assistance with efforts to measure nitrate concentrations continuously at the outlet of the gaging station. 



\section{Contents}

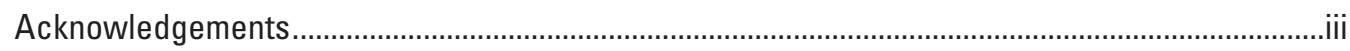

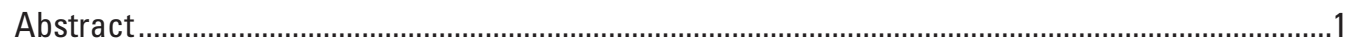

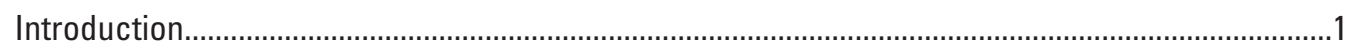

Background and Previous Studies .................................................................................

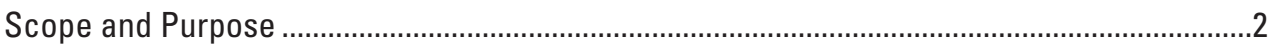

Description of the Study Area ............................................................................................

Methods for Measuring Flux, Water Quality, Sedimentation, and Sea-Level Rise.............................4

Estimation of Runoff and Bidirectional Flow .......................................................................

Continuous Water-Quality Measurement and Ancillary Data ...................................................

Water-Quality Sampling, Laboratory Analysis, and Time Series Analysis ..................................

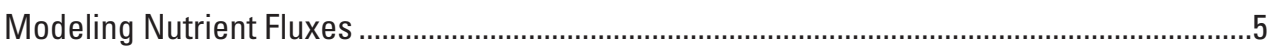

Determination of Mass Accumulation Rates of Sediment.........................................................

Estimating Channel Widening Within Bass Harbor Marsh...................................................... 6

Development of Estuary Bathymetry and Effects of Sea-Level Rise on the Area of

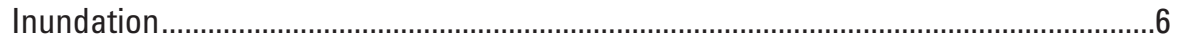

Nutrient Concentrations and Fluxes, Water-Quality, Sedimentation, and Sea-Level Rise................6

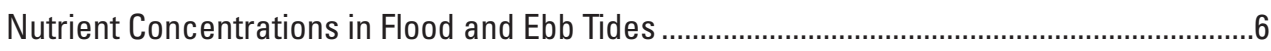

Nutrient Fluxes in 2011 and 2012 ..........................................................................................

Continuously Recorded Water-Quality Measurement............................................................9

${ }^{210} \mathrm{~Pb}$ Chronology and Mass Accumulation Rates of Sediment and Organic Matter ................10

Historical Changes in Estuary and Marsh Area ........................................................................11

Projected Changes in Inundated Area and Estuary Volume ......................................................11

Management Options to Minimize Nutrient Inputs to the Estuary …............................................14

Limitations of this Study and Recommendations for Future Research...........................................14

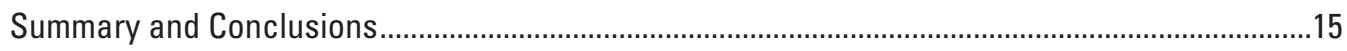

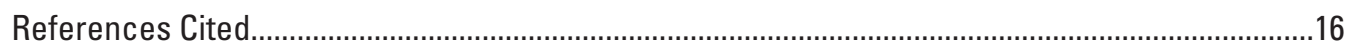

\section{Figures}

1. Map showing the Bass Harbor Marsh watershed on Mount Desert Island, Maine.........3

2. Graph showing weekly ammonium $\left(\mathrm{NH}_{4}\right)$ inputs (from precipitation, watershed runoff, and ebb tides) to and exports (flood tide) from the Bass Harbor Marsh, Mount Desert Island, Maine, Estuary (flood tide) in 2012.

3. Graph showing weekly nitrate $\left(\mathrm{NO}_{3}\right)$ inputs to the estuary (from precipitation, watershed runoff, and ebb tides) and exports from Bass Harbor Marsh, Mount Desert Island, Maine, Estuary (flood tide) in 2012.

4. Map showing the predicted inundated areas within the Bass Harbor Marsh watershed, Mount Desert Island, Maine, mean higher high water (MHHW) following $200-\mathrm{cm}$ sea-level rise with the 95-percent-upper- and lower-limit confidence bounds. 


\section{Tables}

1. Summer seasonal nutrient budgets for the Bass Harbor Marsh estuary, Mount Desert Island, Maine, in 2011 and 2012 .......................................................................

2. Sediment mass accumulation rates and sedimentation rates in the Bass Harbor Marsh estuary, Mount Desert Island, Maine.

3. Summary of sediment mass accumulation rates for the cores collected from the marsh surface in 2011 at Bass Harbor Marsh, Mount Desert Island, Maine ...................11

4. Historical changes in the Bass Harbor Marsh estuary, Mount Desert Island, Maine....11

5. Projected changes in estuary area and in water volume associated with 50-, 100-, and 200-centimenter sea-level rise at mean higher high water and mean lower low water at Bass Harbor Marsh estuary, Mount Desert Island, Maine.

\section{Conversion Factors and Datum}

SI to Inch/Pound

\begin{tabular}{lcl}
\hline \multicolumn{1}{c}{ Multiply } & By & \multicolumn{1}{c}{ To obtain } \\
\hline centimeter $(\mathrm{cm})$ & Length & \\
millimeter $(\mathrm{mm})$ & 0.3937 & inch (in.) \\
meter $(\mathrm{m})$ & 0.03937 & inch (in.) \\
kilometer $(\mathrm{km})$ & 3.281 & foot (ft) \\
\hline & 0.6214 & mile (mi) \\
\hline hectare $(\mathrm{ha})$ & Area & \\
square kilometer $\left(\mathrm{km}^{2}\right)$ & 0.003861 & square mile $\left(\mathrm{mi}^{2}\right)$ \\
square centimeter $\left(\mathrm{cm}^{2}\right)$ & 0.3861 & square mile $\left(\mathrm{mi}^{2}\right)$ \\
\hline & 0.1550 & square inch $\left(\mathrm{ft}^{2}\right)$ \\
\hline liter $(\mathrm{L})$ & Volume & \\
cubic meter $\left(\mathrm{m}^{3}\right)$ & 0.2642 & gallon (gal) \\
\hline & 264.2 & gallon (gal) \\
\hline cubic meter per second $\left(\mathrm{m}^{3} / \mathrm{s}\right)$ & Flow rate & \\
\hline & 35.31 & cubic foot per second $\left(\mathrm{ft}^{3} / \mathrm{s}\right)$ \\
\hline gram $(\mathrm{g})$ & Mass & \\
kilogram $(\mathrm{kg})$ & 0.03527 & ounce, avoirdupois $(\mathrm{oz})$ \\
\hline
\end{tabular}

Temperature in degrees Celsius $\left({ }^{\circ} \mathrm{C}\right)$ may be converted to degrees Fahrenheit $\left({ }^{\circ} \mathrm{F}\right)$ as follows:

${ }^{\circ} \mathrm{F}=\left(1.8 x^{\circ} \mathrm{C}\right)+32$

Vertical coordinate information is referenced to the North American Vertical Datum of 1988 (NAVD 88).

Horizontal coordinate information is referenced to the North American Datum of 1983 (NAD 83).

Elevation, as used in this report, refers to distance above the vertical datum.

Specific conductance is given in microsiemens per centimeter at 25 degrees Celsius $(\mu \mathrm{S} / \mathrm{cm}$ at $\left.25^{\circ} \mathrm{C}\right)$.

Concentrations of chemical constituents in water are given in milligrams per liter (mg/L). 


\section{Abbreviations}

$\begin{array}{ll}\text { ANP } & \text { Acadia National Park } \\ \text { BHM } & \text { Bass Harbor Marsh } \\ \text { CRS } & \text { constant rate of supply }{ }^{210} \mathrm{~Pb} \text { dating method } \\ \text { GPS } & \text { Global Positioning System } \\ \text { lidar } & \text { light detection and ranging } \\ \text { MAR } & \text { mass accumulation rate } \\ \text { MHHW } & \text { mean higher high water } \\ \text { MLLW } & \text { mean lower low water } \\ \text { NADP } & \text { National Atmospheric Deposition Program } \\ \text { NAVD 88 } & \text { North American Vertical Datum of 1988 } \\ \text { NETN } & \text { Northeast Temperate Network } \\ \text { NOAA } & \text { National Oceanographic and Atmospheric Administration } \\ \text { NPS } & \text { National Park Service } \\ \text { NTU } & \text { nephelometric turbidity units } \\ \text { NWIS } & \text { National Water Information System } \\ \text { SLR } & \text { sea-level rise } \\ \text { TDN } & \text { total dissolved nitrogen } \\ \text { TDP } & \text { total dissolved phosphorus } \\ \text { USGS } & \text { U.S. Geological Survey } \\ & \end{array}$





\title{
The Relative Importance of Oceanic Nutrient Inputs for Bass Harbor Marsh Estuary at Acadia National Park, Maine
}

\author{
By Thomas G. Huntington, ${ }^{1}$ Charles W. Culbertson, ${ }^{1}$ Christopher Fuller, ${ }^{1}$ Patricia Glibert, ${ }^{2}$ and Luke Sturtevant ${ }^{1}$
}

\section{Abstract}

The U.S. Geological Survey and Acadia National Park (ANP) collaborated on a study of nutrient inputs into Bass Harbor Marsh Estuary on Mount Desert Island, Maine, to better understand ongoing eutrophication, oceanic nutrient inputs, and potential management solutions. This report includes the estimation of loads of nitrate, ammonia, total dissolved nitrogen, and total dissolved phosphorus to the estuary derived from runoff within the watershed and oceanic inputs during summers 2011 and 2012. Nutrient outputs from the estuary were also monitored, and nutrient inputs in direct precipitation to the estuary were calculated. Specific conductance, water temperature, and turbidity were monitored at the estuary outlet. This report presents a first-order analysis of the potential effects of projected sea-level rise on the inundated area and estuary volume. Historical aerial photographs were used to investigate the possibility of widening of the estuary channel over time. The scope of this report also includes analysis of sediment cores collected from the estuary and fringing marsh surfaces to assess the sediment mass accumulation rate.

Median concentrations of nitrate, ammonium, and total dissolved phosphorus on the flood tide were approximately 25 percent higher than on the ebb tide during the 2011 and 2012 summer seasons. Higher concentrations on the flood tide suggest net assimilation of these nutrients in biota within the estuary. The dissolved organic nitrogen fraction dominated the dissolved nitrogen fraction in all tributaries. The median concentration of dissolved organic nitrogen was about twice as high on the on the ebb tide than the flood tide, indicating net export of dissolved organic nitrogen from the estuary.

The weekly total oceanic inputs of nitrate, ammonium, and total dissolved phosphorus to the estuary were usually much larger than inputs from runoff or direct precipitation. The estuary was a net sink for nitrate and ammonium in most weeks during both years. Oceanic inputs of nitrate and

\footnotetext{
${ }^{1}$ U.S. Geological Survey
}

${ }^{2}$ University of Maryland ammonium were an important source of inorganic nitrogen to the estuary in both years. In both years, the total seasonal inputs of ammonium to the estuary in flood tides were much larger than the inputs from watershed runoff or direct precipitation. In 2011, the total seasonal input of nitrate from flood tides to the estuary was more than twice as large the inputs from watershed runoff and precipitation, but in 2012, the inputs from flood tides were only marginally larger than the inputs from watershed runoff and precipitation. Turbidity was measured intermittently in 2012, and the pattern that emerged from the measurements indicated that the estuary was a source of particulate matter to the ocean rather than the ocean being a source to the estuary.

From the nutrient budgets determined for the estuary it is evident that oceanic sources of nitrate and ammonium are an important part of the supply of nutrients that are contributing to the growth of macroalgae in the estuary. The relative importance of these oceanic nutrients compared with sources within the watershed typically increases as the summer progresses and runoff decreases. It is likely that rising sea levels, estimated by the National Oceanic and Atmospheric Administration to be 11 centimeters from 1950 through 2006 in nearby Bar Harbor, have resulted in an increase in oceanic inputs (tidal volume and nutrients derived from oceanic sources).

\section{Introduction}

\section{Background and Previous Studies}

Eutrophication in estuaries is a priority water-quality issue that continues to be one of the most significant resource management challenges at Acadia National Park (ANP). Coastal salt marshes and wetlands are among the most productive yet threatened ecosystems in North America. Nutrient enrichment poses a severe threat to the integrity and ecological function of estuarine resources at ANP (Doering and others, 1995; Kahl and others, 2000). Previous U.S. Geological Survey (USGS) investigations have considered the susceptibility of estuaries in ANP to elevated nutrient inputs from 
and the threats posed by increasing rural development outside the park's boundaries (Neckles and others, 2003; Culbertson and others, 2007; Nielsen and Kahl, 2007; Huntington and others, 2012). These studies included information about nutrient inputs from terrestrial and atmospheric sources but did not report on oceanic inputs as this study does. Annually recurring nuisance macroalgal blooms have continued to the present [2013] and were reported to be worsening (Doering and others, 1995; David Manski, National Park Service, oral commun., 2012). In addition, there are concerns of shoaling within the estuary and that the estuary is becoming less navigable for recreational boaters. Shoaling may contribute to eutrophication because shallower conditions would result in warmer water, reduced stratification, and more effective light penetration through the water column, leading to increased phytoplankton growth (Lucas and Cloern, 2002).

The general responses of estuaries and coastal ecosystems to excessive nutrient enrichment include increased growth of macroalgae and phytoplankton, subsequent reduction in light penetration leading to loss of seagrass habitat, increased community metabolism, and decreased dissolved oxygen concentrations (Valiela and others 1992; Nixon, 1995; Glibert and others, 2008, 2010).

Although it is reasonable to be concerned with development within the watershed and increasing nutrient loading from land, an assessment of the eutrophication status of the Nation's estuaries revealed that certain estuaries in the northeastern United States with relatively pristine watersheds exhibited eutrophic symptoms (Bricker and others, 1999). This was attributed to the low level of freshwater supply relative to oceanic inputs in these systems. In a trend assessment, Bricker and others (1999) reported that eutrophic conditions in estuaries had worsened between 1970 and 1995 and most were predicted to continue to worsen in a majority of estuaries that they studied. Riverine exports of nitrogen to the near-coastal ocean have also increased with increasing development in the northeastern United States and Canadian maritime provinces (National Research Council, 2000; Howarth, 2008). The frequency, spatial extent, and duration of coastal eutrophication and harmful algal blooms have increased greatly in recent decades due largely to increases in nitrogen inputs (Howarth, 2008). Thus, offshore coastal waters may be the major nutrient source for many estuaries where oceanic contributions are large relative to freshwater drained from the watershed.

Studies on nutrient budgets in estuaries in the northeastern United States have shown complex relationships in which estuaries and their surrounding marsh ecosystems can be either net importers or exporters of organic and inorganic nitrogen and such net exchanges can reverse on short timescales (Tobias and Neubauer, 2009). It is evident that to manage water quality in an estuarine system like the Bass Harbor Marsh (BHM) at Acadia, resource managers need information on the relative importance of different nutrient sources.

\section{Scope and Purpose}

This report details the results of a 2-year field study conducted by the USGS in cooperation with ANP in 2011 and 2012 to determine nutrient sources and nutrient budgets for the BHM Estuary. The report includes the results of an analysis of chronologies of the marsh surface and estuary sediments. Sediment deposition can influence nutrient concentrations within the estuary through microbial mineralization of recently deposited sediments and subsequent release of inorganic nitrogen and phosphorus. Sedimentation can also influence water depth, which in turn can influence water temperature, a factor that can influence nutrient dynamics and eutrophication. This report also includes the results of an investigation of the potential effects of sea-level rise on the inundated area within the BHM watershed and the volume of water in the estuary because these changes could also affect nutrient dynamics and eutrophication. This report includes an evaluation of channel widening using historical aerial photographs to determine whether erosion of channel banks was a plausible explanation for the source of sediments accreting in the estuary. This report draws extensively from Huntington and others (2014), which describes the methods of data collection and provides the data collected during this study. The methods and results are described briefly in this report. The study in this report is distinguished from the study of Huntington and others (2014) in that the goal of this study was to provide ANP resource managers with the interpretation of the data presented in the earlier report. This report discusses potential management options to address water-quality impairment that results in eutrophication as evidenced by extensive macroalgae growth in the estuary. Implementation of these options would require a comprehensive understanding of nutrient sources, seasonal variability, and historical trends, as well as an understanding of sedimentation and ongoing sea-level rise.

\section{Description of the Study Area}

The BHM Estuary is in the southwestern part of Mount Desert Island, in the eastern midcoastal area of Maine. Much of the estuarine system lies within the ANP boundaries. The BHM watershed drains 22 square kilometers $\left(\mathrm{km}^{2}\right)$ and contains several perennial streams, including Adams, Heath, Lurvey, and Marshall Brooks (fig. 1). The land cover is primarily forested and predominantly comprises the sprucefir complex that contains some hardwood species and white pine. Other vegetation types within the watershed include the estuary-fringing salt marsh and wetland complexes along parts of tributary channels. Over a 41-year period (1940-1980), precipitation averaged 123 centimeters per year $(\mathrm{cm} / \mathrm{yr})$ and temperature averaged 8 degrees Celsius $\left({ }^{\circ} \mathrm{C}\right.$; Patterson and others, 1983). ANP is located in the Northeastern Coastal Zone level III ecoregion (U.S. Environmental Protection Agency, 2013) at $44^{\circ} \mathrm{N}$ latitude, and its climate is influenced primarily by maritime conditions. Summers tend to be more moist and 


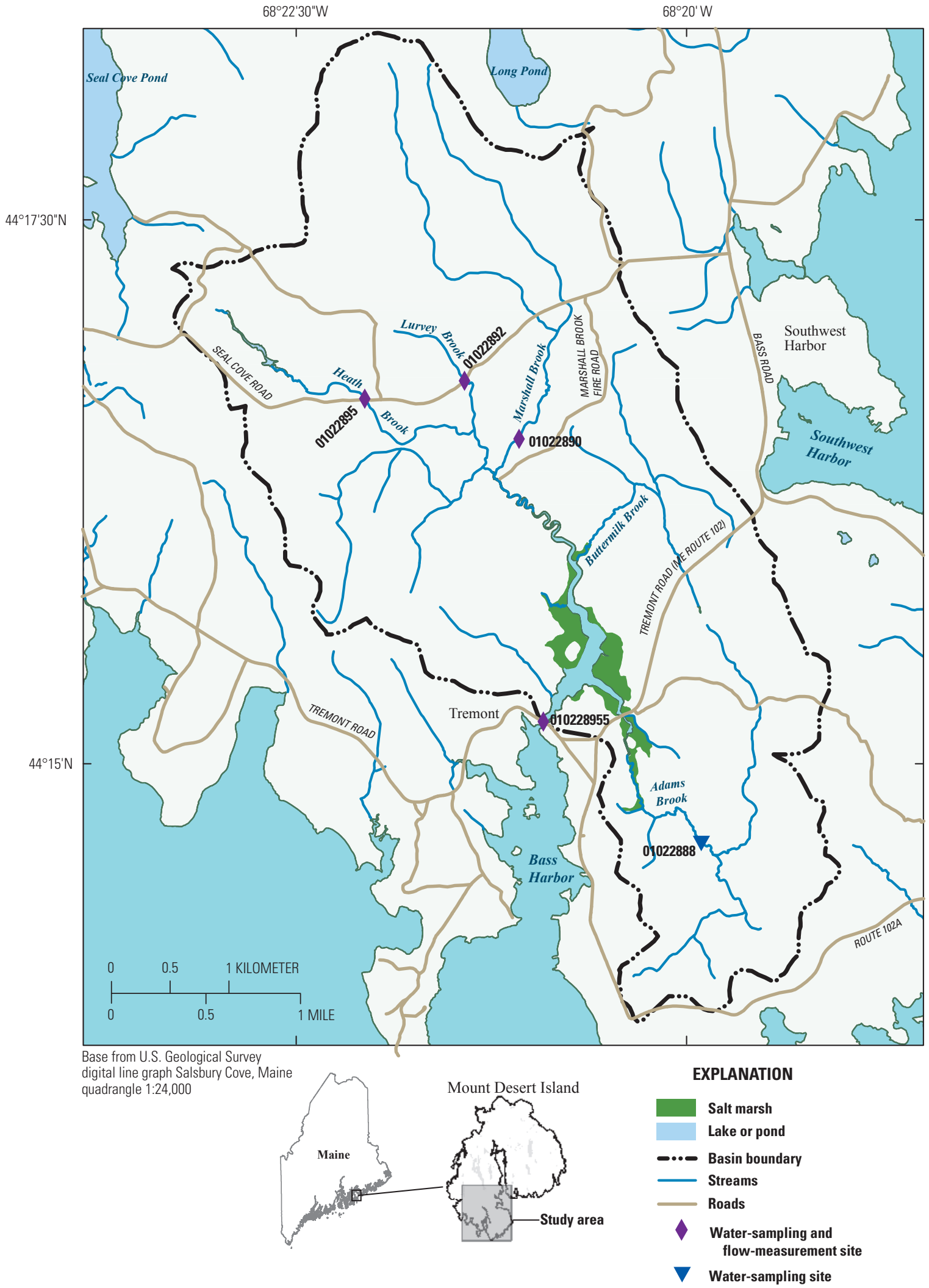

Figure 1. The Bass Harbor Marsh watershed on Mount Desert Island, Maine; modified from Huntington and others (2014). 
cooler than adjacent inland areas, whereas winters tend to be somewhat warmer and experience less snowfall than inland areas (Kahl and others, 2000).

The BHM is a typical estuarine ecosystem, having direct exchange with the ocean through Bass Harbor and freshwater input through several small streams. A bridge on Tremont Road in Tremont, Maine is constructed over a natural bedrock sill that forms the estuary outlet. The bridge opening and bedrock sill dampen the diurnal tidal range from approximately 3 meters $(\mathrm{m})$ in the harbor to less than $1 \mathrm{~m}$ within the marsh, depending on the height of the tide. The estuary is the body of water surrounded by a fringing marsh, and the marsh is flooded for only a few hours each month during the highest tides. The presence of this sill creates an asymmetric tidal flux where flood tides enter the marsh for 2 to 3 hours but ebb tides leave the marsh for 9 to 10 hours (Doering and others, 1995). The water depth within the estuary is shallow, generally less than $0.5 \mathrm{~m}$ at low tide. The system is well flushed, with a residence time of less than 3 days (Kinney and Roman, 1998).

Vegetation within the marsh and the estuary were described by Kinney and Roman (1998). The fringing marsh surface is dominated by short form Spartina alterniflora; in the estuary, Ruppia maritima, a few patches of Zostera marina, and green macroalgae species, principally Enteromorpha prolifera and E. flexuosa, all co-occur.

Signs of eutrophication in the BHM Estuary, the largest tidal marsh estuary on the island, were documented more than 20 years ago (Doering and others, 1995). Evidence of continuing eutrophication in response to input of internal and external sources of nitrogen is noted in the BHM in more recent studies (Kinney and Roman, 1998; Farris and Oviatt, 1999).

\section{Methods for Measuring Flux, Water Quality, Sedimentation, and Sea-Level Rise}

\section{Estimation of Runoff and Bidirectional Flow}

To estimate freshwater inputs to the BHM Estuary during summers 2011 and 2012, first discharge was estimated from the tributaries (Heath [USGS streamgage 01022895], Lurvey [USGS streamgage 01022892], and Marshall [USGS streamgage 01022890] Brooks) using a Move.1 regression analysis (Hirsch, 1982). Continuous discharge measurements were available from nearby Otter Creek (USGS streamgage 01022840) in the USGS National Water Information System (NWIS; U.S. Geological Survey, undated a) and discharge measurements for the tributaries were obtained from ANP staff that had been made as part of the Northeast Temperate Network (NETN) Program (Mitchell and others, 2006). The methods used for estimating runoff from these tributaries and the ungaged areas, including Adams Brook (USGS streamgage 01022888), within the BHM watershed are described in Huntington and others (2014). Discharge at the estuary outlet at the Tremont Road bridge (USGS streamgage 010228955) was measured using the index velocity method (Levesque and Oberg, 2012). The index velocity method is appropriate when more than one specific discharge can be measured for a specific stage as is inherent in a tidally reversing system such as the estuary outlet. This site was especially challenging because of the asymmetric tidal phasing and high velocities during the flood tide. A SonTek Argonaut-SWUplooker was selected for measurement of continuous velocity. The index velocity rating was developed from a series of periodic discharge measurements throughout the measurement season covering more than 90 percent of the observed velocities with an independent acoustic Doppler current profiler following standard USGS procedures (Turnipseed and Sauer, 2010). A detailed description of the methods used to measure bidirectional discharge at the watershed is available in Huntington and others (2014).

\section{Continuous Water-Quality Measurement and Ancillary Data}

Continuous temperature and specific conductance data were collected at a 5-minute time interval using a YSI model 600 OMS V2 sonde during summers 2011 and 2012 (June through September in 2011 and mid-April through September in 2012). Continuous turbidity data were collected from July through September 2012 using an optical sensor with the YSI sonde. In both years, the sonde was deployed at the estuary outlet $1.2 \mathrm{~m}$ upstream and $1.2 \mathrm{~m}$ east (into the channel) from the western abutment of the Tremont Road bridge at a depth of 20 centimeters $(\mathrm{cm})$ above the bedrock sill.

Daily precipitation data for ANP were obtained from the National Park Service (National Atmospheric Deposition Program, undated). The NPS maintains a National Atmospheric Deposition Program (NADP) monitoring site that uses a Belfort tipping bucket rain gage to record daily precipitation at McFarland Hill on Mount Desert Island. Tidal data were obtained from National Oceanic and Atmospheric Administration (NOAA; undated a) data files for Frenchman Bay, Bar Harbor, Maine, on Mount Desert Island.

\section{Water-Quality Sampling, Laboratory Analysis, and Time Series Analysis}

Samples were collected approximately monthly from Adams, Heath, Lurvey, and Marshall Brooks and intermittently on flood and ebb tides from the estuary outlet during May through October in 2008 and 2009 for an earlier project (Huntington and others, 2012) and in 2011 and 2012 for this project. Between 12 and 22 samples were collected from each tributary, except Adams Brook where 8 samples were collected. The analyses were conducted at the Woods Hole Oceanographic Institution Nutrient Analytical Facility (2008 and 2009) and at the University of Maryland Horn Point Lab (2011 and 2012). Additionally the National Park 
Service collected a sample in May and one in August in 2008 and in 2010 from Marshall Brook using the NETN protocols (Mitchell and others, 2006) and these data were supplied to the USGS for use in this analysis. Details of the sampling procedures that varied somewhat between years are described in Huntington and others (2014). Samples were analyzed for ammonium $\left(\mathrm{NH}_{4}\right)$, nitrate (nitrate $\left[\mathrm{NO}_{3}\right]$ plus nitrite $\left[\mathrm{NO}_{2}\right]$ ), total dissolved nitrogen (TDN), and total dissolved phosphorus (TDP), using standard methods described in Huntington and others (2014). Dissolved organic nitrogen (DON) was determined by difference, as follows: $\mathrm{DON}=\mathrm{TDN}-\mathrm{NH}_{4}-$ $\mathrm{NO}_{3}-\mathrm{NO}_{2}$.

Time series analyses of nutrient concentrations in the Heath, Lurvey, and Marshall Brooks in this and previous studies (Doering and others, 1995; Nielsen and Kahl, 2007; Huntington and others, 2012) were conducted to determine whether trends existed over time. Doering and others (1995) reported the average concentrations of Heath and Marshall Brooks as a single value. In this study and in Huntington and others (2012), these brooks were sampled separately, and in Nielsen and Kahl (2007) only Heath Brook was sampled. The drainage area of Heath Brook is nine times larger than that of Lurvey Brook. The nutrient concentrations for Heath and Lurvey Brooks reported by Doering and others (1995), for Heath Brook reported by Nielsen and Kahl (2007), and for Heath Brook measured for this study were used for the time series analysis. The Kendall's tau nonparametric trend test was used, and p-values larger than 0.05 were considered not statistically significant.

\section{Modeling Nutrient Fluxes}

The USGS Load Estimator (LOADEST) regression model (Runkel and others, 2004) was used to estimate hourly nutrient fluxes from Heath, Lurvey, and Marshall Brooks for summers 2011 and 2012. There was substantial variability in the magnitude of the confidence intervals relative to the mean flux estimates depending on the tributary and nutrient. The confidence intervals were usually within the range of 30 to 75 percent of the mean value. Discharge at Adams Brook was estimated using a simple area adjustment applied to Marshall Brook. Nutrient fluxes from the ungaged areas within the BHM watershed were estimated from the area-weighted average fluxes calculated for Heath, Lurvey, and Marshall Brooks. Details of the methodology for load estimation are described in Huntington and others (2014).

The LOADEST regression model was also used to estimate hourly nutrient fluxes across the boundary between ocean and estuary. LOADEST was developed for estimation of elemental loads in rivers based on collection of paired discrete measurements of concentration and discharge and continuous daily discharge estimates. Application of this method to bidirectional flow in an estuary may be unprecedented, but the principles are the same and the uncertainties inherent in the model should be identical to those when the model is applied to a river. Separate models were obtained for each nutrient and for ebb and flood tides because different concentration discharge models were obtained and the objective was to quantify nutrient loads on the ebb and flood tides.

There was substantial variability in the magnitude of the confidence intervals relative to the mean flux estimates depending on the oceanic flux and nutrient. The lower confidence intervals were usually within the range of \pm 6 to 30 percent of the mean value, and the upper confidence intervals were usually within the range of \pm 7 to 40 percent of the mean value. The hourly fluxes were aggregated to compute oceanic fluxes for each complete flood and ebb tide so that water and nutrient inputs could be compared between flood and following ebb tides at various time scales from individual tidal cycles to the complete summer measurement seasons. The nutrient flux data were further aggregated to inputs to the estuary or exports from the estuary on a weekly basis. Weekly estuary inputs minus exports were computed as well as the cumulative weekly input minus export through the summer season. Details of the methodology for load estimation are described in Huntington and others (2014).

\section{Determination of Mass Accumulation Rates of Sediment}

Four sediment cores were collected in 2009 by hand from a small boat with a push corer from various locations in the estuary. Five marsh surface cores were collected in 2011 using a Hargis corer, a razor-edged piston (15-cm diameter) corer that minimizes soil compaction (Hargis and Twilley, 1994). Freeze-dried subsections of the surface cores from the estuary and marsh were analyzed at for lead-210 $\left({ }^{210} \mathrm{~Pb}\right)$, radium-226 $\left({ }^{226} \mathrm{Ra}\right)$, cesium-137 $\left({ }^{137} \mathrm{Cs}\right)$, and beryllium-7 $\left({ }^{7} \mathrm{Be}\right)$ radioactivity to estimate sediment accumulation rates for assigning dates to core profiles. Sediment mass accumulation rates (MAR; in grams per square centimeter per year) were determined using the constant rate of supply ${ }^{210} \mathrm{~Pb}$ dating method for the profiles in the estuary and marsh (Appleby and Oldfield, 1992). ${ }^{210} \mathrm{~Pb}$ activities greater than the ${ }^{226} \mathrm{Ra}$ activity are termed unsupported or excess ${ }^{210} \mathrm{~Pb}$. Unsupported ${ }^{210} \mathrm{~Pb}$ in sediments results from the emanation of ${ }^{222} \mathrm{Rn}$ gas from continental land masses to the atmosphere. Details of the locations of sediment cores, sectioning and sample handling procedures, and analytical methods are described in Huntington and others (2014). The resulting sediment accumulation rates were used to calculate the age range of each interval as calendar dates before present. In addition to MAR, sedimentation rates were determined for specific time increments among cores from the estuary to identify changes over time. Marsh accretion rate was determined by dividing the maximum depth of measurable unsupported ${ }^{210} \mathrm{~Pb}$ by the difference between the surface date and the date at this depth. Sedimentation rate (in centimeters per year) was calculated by multiplying the cumulative dry mass (in grams per square centimeter) by the interval thickness (centimeter) and dividing the interval of interest by the MAR (in grams per square centimeter per year). 


\section{Estimating Channel Widening Within Bass Harbor Marsh}

Historical aerial photographs (from 1944, 1955, 1964, 1979, and 1997) were georeferenced and compiled together with the Microsoft Bing map online resource (Microsoft Bing Maps, 2010) in a geodatabase in Esri ArcMap 10.1 to delineate the estuary channel and fringing marsh. The estuary and marsh boundaries were used to create polygons with consistent downstream extents, and the area of each polygon was calculated. A previously delineated polygon of BHM (Nielsen and Dudley, 2013) was used to represent the areal extent of BHM in 2010. Nielsen and Dudley (2013) used light detection and ranging (lidar)-derived digital elevation models, land-surveyed control points, and digital color aerial photography taken during low tide conditions in 2008 to define the boundary between upland and marsh. It was assumed that the boundary between upland and marsh defined by Nielsen and Dudley (2013) remained constant from the date of the earliest aerial image (1944) until the present [2013] and reflected the elevation of mean higher high water (MHHW) that is sometimes used as an alternative to the boundary between upland and marsh.

Because sea level has risen by about $11 \mathrm{~cm}$ since 1950 in nearby Bar Harbor (National Oceanic and Atmospheric Administration, undated $b$ ), this boundary may have migrated landward somewhat, but the movement would be small compared with the movement that would accompany the sealevel rise scenarios evaluated in this study and the associated changes in marsh area. The marsh surface area was calculated as the area of the polygons formed from the boundaries between the estuary and the marsh on the one hand and the marsh and the upland and forest on the other. Further details on the methods used to delineate the estuary and marsh polygons are provided in Huntington and others (2014).

\section{Development of Estuary Bathymetry and Effects of Sea-Level Rise on the Area of Inundation}

Bathymetric data were collected using a timesynchronized Teledyne RD Instruments RiverRay acoustic Doppler current profiler coupled with a high precision global positioning system (GPS). The resulting bottom-elevation data files were processed in Esri ArcMap 10.1 for bathymetric mapping. Details of the methodology for bathymetric measurements are described in Huntington and others (2014).

To estimate the effect of sea-level rise on the inundated area within BHM, the effects of 50, 100, and $200 \mathrm{~cm}$ of sea-level rise (Parris and others, 2012) on marsh area using lidar-derived elevation data following the method of Gesch and others (2009) were evaluated. The area and the volume of water in the estuary at MHHW and mean lower low water (MLLW) under current [2013] conditions were compared with the changes in area and volume associated with sea-level rise of 50,100, and $200 \mathrm{~cm}$. On the basis of measurements of the change in water levels within the estuary over the range of observed ocean tidal elevations, it was assumed that the water level in the estuary would increase by 60 percent from that observed in the ocean. The effective increases in MHHW and MLLW in the estuary associated with the sea-level rise scenarios of 50,100 , and $200 \mathrm{~cm}$ were then 30,60 , and $120 \mathrm{~cm}$, respectively.

Contours were created from lidar data using a model builder tool constructed for a previous USGS study on the effects of sea-level rise on salt marshes (Nielsen and Dudley, 2013). That study determined the lidar accuracy to be within $26 \mathrm{~cm}$ vertically of high-accuracy GPS survey points within the BHM area. For this reason, sea-level rise contours were constructed in such a way as to have an upper and lower confidence contour of $26 \mathrm{~cm}$. The high marsh elevations were determined by constructing polygons of the salt marsh area using high-resolution aerial photographs provided by the 2010 Microsoft Bing map online resource (Microsoft Bing Maps, 2010). Lidar data were used to assign elevations to the edges of the salt marsh polygons where the salt marsh ends and forest or other vegetation begins. These salt marsh polygons attributed to high marsh elevations were obtained from the USGS Acadia salt-marsh study database (Nielsen and Dudley, 2013). The high elevation contours were used to see the difference in present high tide inundation and future sea-level rise conditions. After construction of the different polygons representing different inundated areas associated with 50, 100, and $200 \mathrm{~cm}$ of sea-level rise, these polygons were merged with the bathymetric and lidar elevation data to compute the volume of water in the estuary during these high tide conditions at each sea-level rise scenario.

\section{Nutrient Concentrations and Fluxes, Water-Quality, Sedimentation, and Sea-Level Rise}

Continuous temperature, specific conductance, and turbidity data at the estuary outlet are available from NWIS (U.S. Geological Survey, undated f). Data for concentrations of $\mathrm{NH}_{4}, \mathrm{NO}_{3}$ plus $\mathrm{NO}_{2}, \mathrm{TDN}$, and TDP are available from NWIS (U.S. Geological Survey, undated g). The sediment isotopic data are presented in graphical form in Huntington and others (2014). Tabulations of the isotopic data are available from the Maine Water Science Center in Augusta, Maine.

\section{Nutrient Concentrations in Flood and Ebb Tides}

Median concentrations of $\mathrm{NO}_{3}, \mathrm{NH}_{4}$, and TDP on the flood tide (0.0097 milligrams per liter $(\mathrm{mg} / \mathrm{L}), 0.025 \mathrm{mg} / \mathrm{L}$, and $0.023 \mathrm{mg} / \mathrm{L}$, respectively) were approximately 25 percent higher than on the ebb tide during the 2011 and 2012 summer seasons (Huntington and others, 2014). The median concentrations for $\mathrm{NO}_{3}$ and TDP on the flood tide observed 
in this study were very similar to those reported by Doering and others (1995) for flood tide in this estuary. However, the median concentration of $\mathrm{NH}_{4}$ on the flood tide determined in this study was four times higher than what Doering and others (1995) reported. The Doering and others (1995) study included only five to six samples, whereas for this study, between 67 and 74 samples, depending on the nutrient, were analyzed. Higher concentrations on the flood tide suggest net assimilation of these nutrients by biota within the estuary. The median concentration of dissolved organic nitrogen (DON) was about twice as high as on the ebb (0.087 milligrams of nitrogen per liter [mg N/L] tide than the flood tide $(0.041 \mathrm{mg} \mathrm{N} / \mathrm{L})$ indicating net export of DON, which is consistent with studied conducted in other estuarine systems (Tobias and Neubauer, 2009).

The median concentration of $\mathrm{NO}_{3}$ in Adams, Heath, and Lurvey Brooks was similar to what was observed on the ebb tide, but the $\mathrm{NO}_{3}$ concentration in Marshall Brook was an order of magnitude higher $(0.08 \mathrm{mg} \mathrm{N} / \mathrm{L})$. The median concentration of $\mathrm{NH}_{4}$ was higher in Adams Brook $(0.043 \mathrm{mg} \mathrm{N} / \mathrm{L})$ and lower in Marshall Brook (0.013 mg N/L). $\mathrm{NH}_{4}$ concentrations were higher than $\mathrm{NO}_{3}$ concentrations in Adams, Heath, and Lurvey Brooks but substantially lower than $\mathrm{NO}_{3}$ concentrations in Marshall Brook. Median TON concentrations were highest in Adams Brook $(0.69 \mathrm{mg} \mathrm{N} / \mathrm{L})$ and lowest in Marshall Brook (0.29 mg N/L). The dissolved organic nitrogen fraction dominated the dissolved nitrogen fraction in all tributaries. Median TDP concentrations were highest in Adams Brook (0.019 mg P/L) and lowest in Marshall Brook $(0.005 \mathrm{mg} \mathrm{P} / \mathrm{L})$. There was little seasonal variation in inorganic nitrogen or TDP concentrations, however, dissolved organic nitrogen concentrations tended to be highest during August and September. Box plots illustrating the differences in concentration are provided in Huntington and others (2014), and the data are available from NWIS (U.S. Geological Survey, undated a-g). Based on the data reported in Doering and others (1995), Nielsen and Kahl (2007), Huntington and others (2012), and this study, there were no statistically significant trends in concentrations of $\mathrm{NH}_{4}, \mathrm{NO}_{3}, \mathrm{TDN}$, and TDP in Marshall Brook or in Heath and Lurvey Brooks from 1990 through 2012.

\section{Nutrient Fluxes in 2011 and 2012}

The magnitudes of oceanic nutrient fluxes followed the cycle of spring and neap tides (being highest on spring and lowest on neap tides) and were generally greatest during late May and June when runoff was greatest. Nutrient fluxes on ebb tides increased following major precipitation events, which in turn corresponded with periods of the greatest runoff in the area recorded at nearby Otter Creek. Net tidal exchange (flood minus following ebb) of $\mathrm{NH}_{4}$ tended to be negative (ebb flux larger than flood flux) in late May and June and positive or neutral before and after that. Net tidal exchange of $\mathrm{NO}_{3}$ was negative throughout the season in 2011, especially in September, and in 2012, it was mostly negative before mid-June, neutral until mid- to late August, and positive after that. Net tidal exchange of TDN was negative throughout most of 2011 and all of 2012. Net tidal exchange of total TDP was mostly negative in 2011 and neutral in most of 2012. Watershed runoff plus precipitation generally supplied proportionately more of the total inputs of $\mathrm{NO}_{3}$ to the estuary than of $\mathrm{NH}_{4}$. During the dry summer months, oceanic inputs supplied proportionately more $\mathrm{NH}_{4}$ and $\mathrm{NO}_{3}$ to the estuary than they did in the wet spring months.

Weekly total oceanic inputs and exports of $\mathrm{NH}_{4}$ to the estuary were usually much larger (by a factor of 10 or more) than inputs in runoff or direct precipitation, except during 2012 following periods of high runoff when they were only larger by a factor of about 2 to 3 (fig. 2). Ebb tide exports of $\mathrm{NH}_{4}$ from the estuary were larger than flood tide inputs to the estuary until the end of June in 2011 and until mid-July in 2012; after that, flood tide inputs were larger than ebb tide exports in 2011 and nearly identical to flood tide inputs in 2012. In 2011, $\mathrm{NH}_{4}$ inputs to the estuary exceeded outputs in almost all weeks, resulting in a cumulative net input of 150 kilograms of nitrogen from May 24 through September 27 (table 1). From mid-June through the end of September 2011, the estuary was a net sink for $\mathrm{NH}_{4}$ at a rate of 1.5 kilograms of nitrogen per day ( $\mathrm{kg} \mathrm{N} / \mathrm{d})$. In 2012, $\mathrm{NH}_{4}$ inputs to and outputs from the estuary were nearly balanced for the similar period from May 22 through September 25. The major difference between years was that from late May through mid-July, $\mathrm{NH}_{4}$ exports were substantially larger than inputs in 2012 compared with 2011. The larger inputs during this period in 2012 were because of substantially greater runoff in 2012 compared with 2011. The average estimated discharge from tributaries to the estuary from May 1 to October 15 was 0.82 cubic meter per second $\left(\mathrm{m}^{3} / \mathrm{s} ; 28.8\right.$ cubic feet per second $\left.\left[\mathrm{ft}^{3} / \mathrm{s}\right]\right)$ in 2012 compared with $0.52 \mathrm{~m}^{3} / \mathrm{s}\left(18.4 \mathrm{ft}^{3} / \mathrm{s}\right)$ in 2011 . In spite of the high $\mathrm{NH}_{4}$ exports in late May and June, the estuary lost $\mathrm{NH}_{4}$ at a rate of $0.69 \mathrm{~kg} \mathrm{~N} / \mathrm{d}$ from the week ending July 10 through September 25. Oceanic inputs of $\mathrm{NH}_{4}$ were an important source of inorganic nitrogen to the estuary in both years, and in absolute terms, inputs of $\mathrm{NH}_{4}$ in flood tides were much larger than inputs in watershed runoff or in direct precipitation (table 1).

Weekly total oceanic inputs and exports of $\mathrm{NO}_{3}$ to the estuary were usually much larger (by factors ranging from 2 to 20) than inputs in runoff or direct precipitation, except during 2012, following periods of high runoff, when they were similar (fig. 3). Flood tide inputs of $\mathrm{NO}_{3}$ to the estuary were larger than ebb tide exports throughout 2011 and in all but one week in 2012. The cumulative $\mathrm{NO}_{3}$ inputs-exports curve increased steadily in 2011 and 2012, illustrating a pattern of net loss within the estuary of $1.9 \mathrm{~kg} \mathrm{~N} / \mathrm{d}$ in 2011 and $1.7 \mathrm{~kg} \mathrm{~N} / \mathrm{d}$ in 2012 . The estuary was a net sink for $\mathrm{NO}_{3}$ of 250 kilograms of nitrogen $(\mathrm{kg} \mathrm{N})$ from May 24 through September 27 in 2011, and $230 \mathrm{~kg} \mathrm{~N}$ from May 22 through September 25 in 2012 (table 1). Oceanic inputs of $\mathrm{NO}_{3}$ were an important source of inorganic nitrogen to the estuary in 


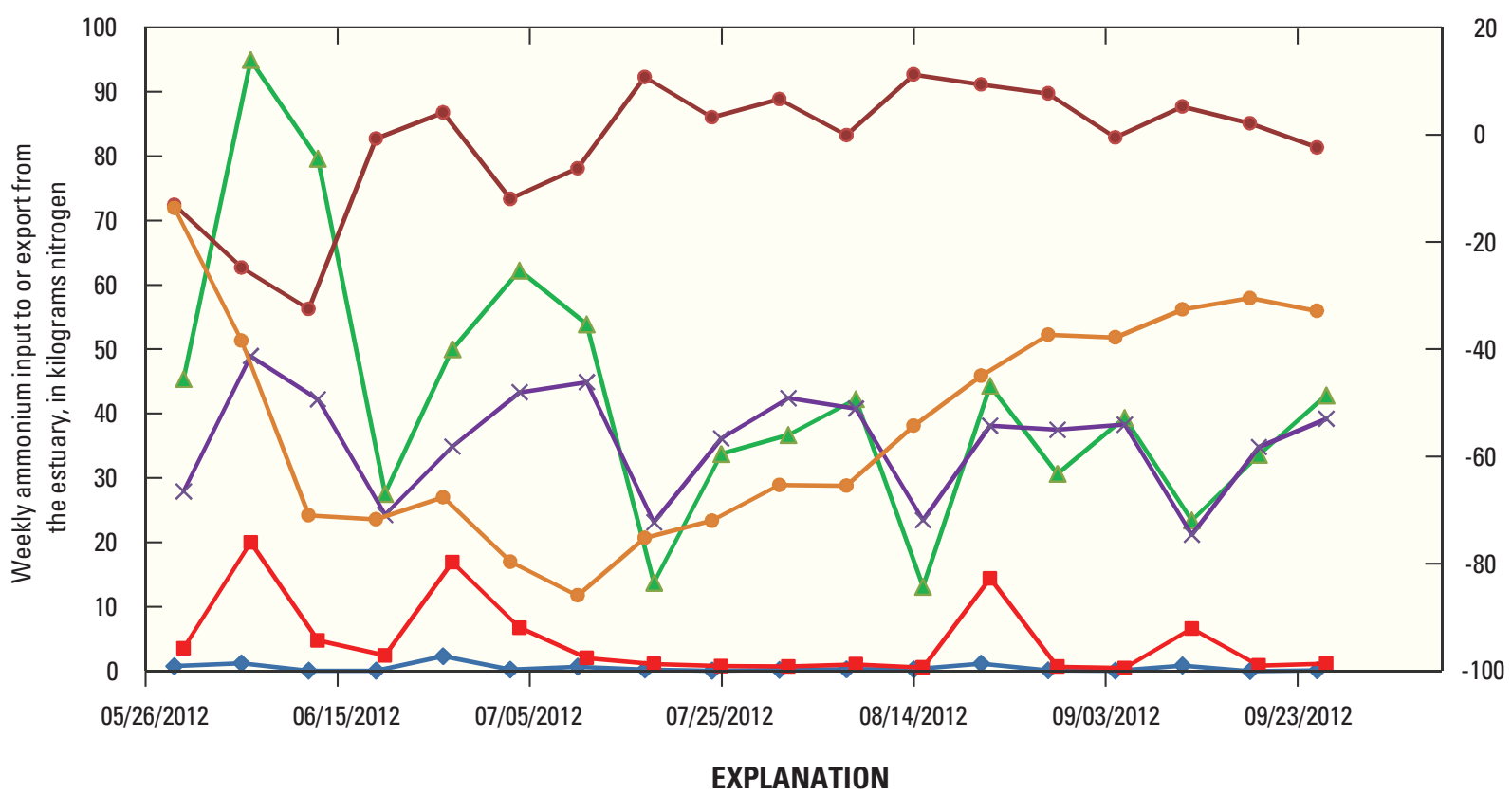

$\multimap$ Precipitation $\multimap-$ Watershed runoff $\longrightarrow$ Ebb tide $\multimap$ Flood tide $\multimap$ Weekly input-export $\multimap$ Cumulative input-export

Figure 2. Weekly ammonium $\left(\mathrm{NH}_{4}\right)$ inputs (from precipitation, watershed runoff, and ebb tides) to and exports (flood tide) from the Bass Harbor Marsh, Mount Desert Island, Maine, Estuary (flood tide) in 2012. The graph also shows weekly $\mathrm{NH}_{4}$ input-export (net change) and cumulative $\mathrm{NH}_{4}$ input-export in 2012.

Table 1. Summer seasonal nutrient budgets for the Bass Harbor Marsh estuary, Mount Desert Island, Maine, in 2011 and 2012.

$\left[\mathrm{kg}\right.$, kilograms; $\mathrm{NH}_{4}-\mathrm{N}$, ammonium as nitrogen; $\mathrm{NO}_{3}-\mathrm{N}$, nitrate as nitrogen; TDN, total dissolved nitrogen; TDP, total dissolved phosphorus; TON, total organic nitrogen; NA, not available]

\begin{tabular}{|c|c|c|c|c|c|c|}
\hline \multirow{2}{*}{ Component of nutrient budget } & \multirow{2}{*}{ Exchange $^{1}$} & \multicolumn{5}{|c|}{ Nutrient budget data, in kg } \\
\hline & & $\mathrm{NH}_{4}-\mathrm{N}$ & $\mathrm{NO}_{3}-\mathrm{N}$ & TDN & TDP & TON \\
\hline \multicolumn{7}{|c|}{2011 (May 24 through September 27) } \\
\hline Watershed runoff & Input & 50 & 110 & 1,200 & 26 & 1,000 \\
\hline Direct precipitation & Input & 6.3 & 26 & NA & NA & NA \\
\hline Flood tide & Input & 650 & 380 & 2,600 & 480 & 1,600 \\
\hline Ebb tide & Export & 560 & 270 & 3,400 & 530 & 2,600 \\
\hline Residual $^{2}$ & Net & 150 & 250 & 400 & -24 & 0 \\
\hline \multicolumn{7}{|c|}{2012 (May 22 through September 25) } \\
\hline Watershed runoff & Input & 84 & 170 & 2,600 & 63 & 2,300 \\
\hline Direct precipitation & Input & 8.6 & 30 & NA & NA & NA \\
\hline Flood tide & Input & 640 & 230 & 1,500 & 470 & 630 \\
\hline Ebb tide & Export & 770 & 200 & 3,500 & 490 & 2,500 \\
\hline Residual $^{2}$ & Net & -37 & 230 & 400 & 36 & 230 \\
\hline
\end{tabular}

${ }^{1}$ Exchange refers to the direction of nutrient load with respect to the estuary. Loads are inputs to the estuary, exports from the estuary, or the net exchange (sum of inputs minus sum of exports).

${ }^{2}$ The residual is with respect to the estuary during sequential flood followed by ebb tides, calculated as follows: residual $=($ flood + watershed runoff + direct precipitation) - ebb. If the residual is positive, then inputs to the estuary were larger than exports, implying consumption within the estuary (uptake, absorption, or flocculation/sedimentation). If the residual is negative, then exports from the estuary are greater than inputs, implying that the estuary is a net source to the ocean. 


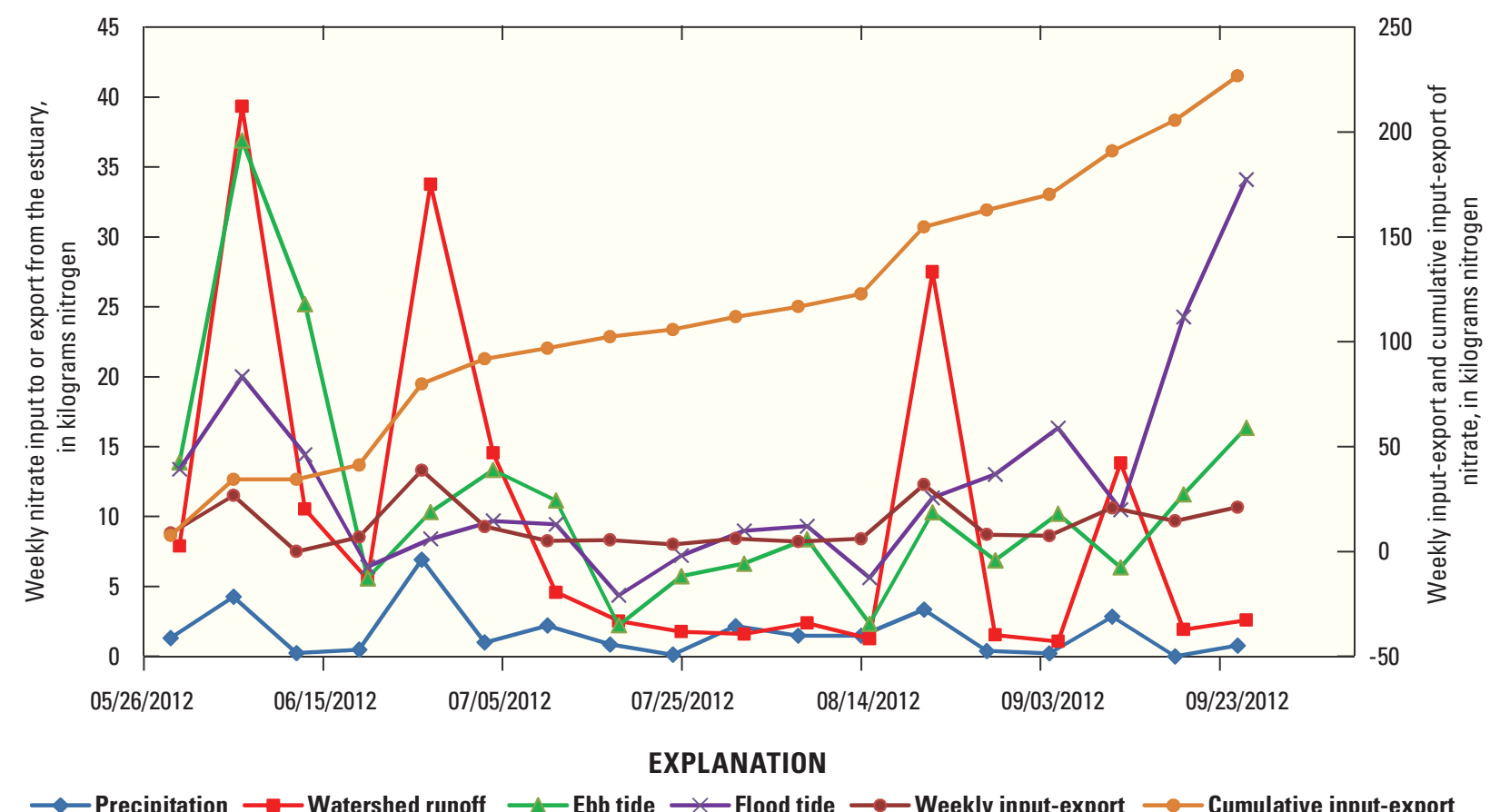

Figure 3. Weekly nitrate $\left(\mathrm{NO}_{3}\right)$ inputs to the estuary (from precipitation, watershed runoff, and ebb tides) and exports from Bass Harbor Marsh, Mount Desert Island, Maine, Estuary (flood tide) in 2012. The graph also shows weekly $\mathrm{NO}_{3}$ inputexport (net change) and cumulative $\mathrm{NO}_{3}$ input-export in 2012.

both years, and in absolute terms, inputs of $\mathrm{NO}_{3}$ in flood tides were larger than inputs in watershed runoff or in direct precipitation (table 1). Similarly to the seasonal pattern observed for $\mathrm{NH}_{4}$, flood tides were usually the dominant source of $\mathrm{NO}_{3}$ to the estuary in both years, with the exception of two weeks after large runoff events in 2012.

Oceanic inputs of TDP to the estuary were larger than inputs in runoff and direct precipitation by more than a factor of 10 in most weeks in 2011 and 2012. In 2011, the estuary was a net sink (TDP was lost) until mid- July, and from midJuly to mid-August the estuary was a net source to the ocean (Huntington and others, 2014, figs. 29 and 30). From midAugust through the end of September, inputs were generally balanced by exports. In contrast, in 2012, the estuary was a net sink in most weeks. The majority of cumulative exports in 2012 occurred from late May through the end of June. Inputs were balanced by exports from late June though the end of July. Oceanic inputs of TDP were an important source of inorganic phosphorus to the estuary compared with inputs in watershed runoff in both years, and TDP inputs were nearly balanced by outputs in both years (table 1 ).

\section{Continuously Recorded Water-Quality Measurement}

Specific conductance recorded at the estuary outlet during the summer seasons in 2011 and 2012 illustrated differences in water quality between years (Huntington and others, 2014). During periods of higher runoff following rainstorms, specific conductance at the estuary outlet decreased substantially from values in excess of 45,000 microsiemens per centimeter at 25 degrees Celsius $\left(\mu \mathrm{S} / \mathrm{cm}\right.$ at $\left.25^{\circ} \mathrm{C}\right)$, characteristic of oceanic inputs on the flood tide, to values less than $20,000 \mu \mathrm{S} / \mathrm{cm}$ at $25^{\circ} \mathrm{C}$. There were four such events between May 1 and July 1 in 2012, and none during the corresponding period in 2011 (Huntington and others, 2014); published data are available from NWIS (U.S. Geological Survey, undated a-g). In 2012, water temperature at the estuary outlet increased from June 1 through mid-July, remained high until late August, and then decreased through the end of September (Huntington and others, 2014). Published data are available from NWIS (U.S. Geological Survey, undated a-g). The average water temperature $\left(17^{\circ} \mathrm{C}\right)$ for all dates and times with corresponding records available in each year from June through September was nearly identical between years. Water temperature at the outlet was closely related to water level (specific stage) in the estuary. Water temperature was warmest during neap tides compared with spring tides and warmest at the end of ebb tides when the water in the estuary was shallowest compared with flood tides.

Turbidity was recorded at the estuary outlet for most of the period from July 12 through October 3, 2012, although there was a gap in the data from August 5 through August 25. Turbidity was usually less than 10 nephelometric turbidity 
units (NTU), with the exception of a brief period in early September when turbidity increased to about 40 NTU following a rainfall event. Within 10 days after the event, turbidity gradually returned to conditions similar to those before the storm (Huntington and others, 2014). Published data are available from NWIS (U.S. Geological Survey, undated a-g). Although there were fewer than 3 months' worth of continuous turbidity data, turbidity followed a consistent pattern such that it decreased rapidly at the beginning of each flood tide to a minimum at the end of the flood tide and then increased throughout the duration of the ebb tide, reaching a maximum at the end of the ebb tide. This pattern indicates that the estuary is a source of particulate matter to the ocean rather than the ocean being a source to the estuary. This finding may have implications for sediment supply required to maintain marsh surface elevation as sea level rises.

\section{${ }^{210} \mathrm{~Pb}$ Chronology and Mass Accumulation Rates of Sediment and Organic Matter}

The ${ }^{210} \mathrm{~Pb}$ analysis of the four cores collected in the estuary indicated that the MARs of sediment were very similar among cores and indicated an increase in sediment accumulation rate around 1960. Before 1930, the MARs were 0.02 to 0.03 gram per square centimeter per year $\left(\mathrm{g} / \mathrm{cm}^{2} / \mathrm{yr}\right)$ and increased to $0.04 \mathrm{~g} / \mathrm{cm}^{2} / \mathrm{yr}$ from 1930 to 1960 (table 2). From 1960 to 1980 , the MARs more than doubled to 0.07 to $0.09 \mathrm{~g} / \mathrm{cm}^{2} / \mathrm{yr}$, and from 1980 to 2009 , they ranged from 0.09 to $0.11 \mathrm{~g} / \mathrm{cm}^{2} / \mathrm{yr}$. The corresponding sedimentation rates ranged from $0.1 \mathrm{~cm} / \mathrm{yr}$ before 1930 to $0.5 \mathrm{~cm} / \mathrm{yr}$ after 1980 . These recent high rates of sedimentation within the estuary are consistent with anecdotal reports of shoaling. Results of the radioisotope analyses for the estuary cores are discussed in more detail in Huntington and others (2014).

A summary of the MARs for total sediment (organic plus inorganic mass) determined for the five cores collected from the marsh surface (eastern and western sides of the estuary) in 2011 shows a range from 0.018 to $0.036 \mathrm{~g} / \mathrm{cm}^{2} / \mathrm{yr}$ from the early 1900s through 2011 (table 3), with the average for the five sites being $0.025 \pm .007 \mathrm{~g} / \mathrm{cm}^{2} / \mathrm{yr}$. The locations of the coring sites are shown in Huntington and others (2014, fig. 5). For most core sampling sites, the MAR was greater at the surface than at the bottom of the marsh, with the greatest differences in MAR observed at the two sites on the west side of the estuary. The accretion rate of the marsh was calculated from the thickness of the dated section divided by the difference between the surface age and the ${ }^{210} \mathrm{~Pb}$-derived age at the bottom; for example, in core $\mathrm{S} 1$, the 19-cm horizon dates to 1902 , so $19 \mathrm{~cm} /(2011-1902)=0.22 \mathrm{~cm} / \mathrm{yr}$. The range in accretion rate during the past 100 years is 0.14 to $0.22 \mathrm{~cm} / \mathrm{yr}$ and the average accretion rate was $0.18 \pm 0.03 \mathrm{~cm} / \mathrm{yr}$ or $1.8 \pm 0.3 \mathrm{mil}-$ limeters per year $(\mathrm{mm} / \mathrm{yr})$. Based on tidal data from NOAA gage 8413320 in nearby Bar Harbor, sea-level rise between 1947 and 2011 was $2.18 \pm 0.26 \mathrm{~mm} / \mathrm{yr}$ (National Oceanic and Atmospheric Administration, undated $b$ ). The data indicated marsh accretion has kept up with sea-level rise in this marsh. A summary of the sedimentary accretion rates determined for the five cores collected from the marsh surface (eastern and western sides of the estuary) in 2011 show generally greater rates of accretion ( 0.20 to $0.29 \mathrm{~cm} / \mathrm{yr})$ from about 1980 to 2011. The sedimentary accretion rates are 15 to 70 percent lower ( 0.06 to $0.25 \mathrm{~cm} / \mathrm{yr}$ ) for the earlier part of the 20th century, with the greater difference in rate observed in the eastern side of the estuary. Results of the ${ }^{210} \mathrm{~Pb}$ analysis for the marsh surface cores are discussed in more detail in Huntington and others (2014).

Table 2. Sediment mass accumulation rates and sedimentation rates in the Bass Harbor Marsh estuary, Mount Desert Island, Maine.

[Data are from cores collected from the estuary. Total represents the total sediment mass accumulation rate, and ORG represents the organic matter mass accumulation rate. BHM.0X, Bass Harbor Marsh sample number; NA, not available; XX, not applicable]

\begin{tabular}{|c|c|c|c|c|c|c|c|c|}
\hline & \multicolumn{2}{|c|}{ BHM.01 } & \multicolumn{2}{|c|}{ BHM.02 } & \multicolumn{2}{|c|}{ BHM.03 } & \multicolumn{2}{|c|}{ BHM.04 } \\
\hline & Total & ORG & Total & ORG & Total & ORG & Total & ORG \\
\hline \multicolumn{9}{|c|}{ Mass accumulation rate, in grams per square centimeter per year } \\
\hline 1980-2009 & 0.11 & 0.017 & 0.09 & 0.014 & 0.1 & 0.015 & 0.09 & 0.014 \\
\hline 1960-1980 & 0.09 & 0.013 & 0.06 & 0.01 & 0.09 & 0.012 & 0.07 & 0.012 \\
\hline 1930-1960 & 0.04 & 0.006 & 0.04 & 0.006 & 0.05 & 0.007 & 0.04 & 0.006 \\
\hline Before 1930 & 0.02 & 0.002 & NA & NA & 0.03 & 0.004 & 0.02 & 0.004 \\
\hline \multicolumn{9}{|c|}{ Sedimentation rate at surface, in centimeters per year } \\
\hline 1980-2009 & 0.5 & $\mathrm{XX}$ & 0.4 & $\mathrm{XX}$ & 0.4 & $\mathrm{XX}$ & 0.5 & $\mathrm{XX}$ \\
\hline 1960-1980 & 0.4 & $\mathrm{XX}$ & 0.3 & $\mathrm{XX}$ & 0.3 & $\mathrm{XX}$ & 0.4 & $\mathrm{XX}$ \\
\hline 1930-1960 & 0.2 & $\mathrm{XX}$ & 0.2 & $\mathrm{XX}$ & 0.2 & $\mathrm{XX}$ & 0.2 & $\mathrm{XX}$ \\
\hline Before 1930 & 0.1 & XX & XX & $\mathrm{XX}$ & 0.1 & XX & $\mathrm{XX}$ & XX \\
\hline
\end{tabular}


Table 3. Summary of sediment mass accumulation rates for the cores collected from the marsh surface in 2011 at Bass Harbor Marsh, Mount Desert Island, Maine.

[Sites of collection of sediment cores are from Huntington and others (2014, fig. 5). ${ }^{210} \mathrm{~Pb}$, lead-210 isotope; $\mathrm{Bq} / \mathrm{cm}^{2}$, becquerels per square centimeter; cm/yr, centimeters per year; MAR, mass accumulation rate; $\mathrm{g} / \mathrm{cm}^{2} / \mathrm{yr}$, grams per square centimeter per year; ${ }^{137} \mathrm{Cs}$, cesium-137 isotope; cm, centimeters; CRS, constant rate of supply lead-210 $\left({ }^{210} \mathrm{~Pb}\right)$ isotope dating method; --, not measured]

\begin{tabular}{|c|c|c|c|c|c|c|c|c|}
\hline $\begin{array}{c}\text { Site } \\
\text { (core identifica- } \\
\text { tion number) }\end{array}$ & $\begin{array}{l}\text { Unsupported }{ }^{210} \mathrm{~Pb} \\
\text { inventory excess, } \\
\text { in } \mathrm{Bq} / \mathrm{cm}^{2}\end{array}$ & $\begin{array}{c}\text { Dated range, } \\
\text { from year } \\
\text { shown to } 2011\end{array}$ & $\begin{array}{l}\text { Accretion } \\
\text { range, } \\
\text { in } \mathrm{cm} / \mathrm{yr}\end{array}$ & $\begin{array}{l}\text { Total MAR, } \\
\text { in } \mathrm{g} / \mathrm{cm}^{2} / \mathrm{yr}\end{array}$ & $\begin{array}{c}\text { Organic } \\
\text { MAR, } \\
\text { in } \mathbf{g} / \mathbf{c m}^{2} / \mathbf{y r}\end{array}$ & $\begin{array}{c}\text { Inorganic } \\
\text { MAR, } \\
\text { in } \mathbf{g} / \mathrm{cm}^{2} / \mathrm{yr}\end{array}$ & $\begin{array}{l}{ }^{137} \text { Cs peak } \\
\text { depth, } \\
\text { in } \mathrm{cm}\end{array}$ & $\begin{array}{l}\text { CRS date of } \\
{ }^{137} \text { Cs peak }\end{array}$ \\
\hline BHM.S1 & 1.33 & 1902 & 0.22 & 0.036 & 0.015 & 0.0230 & $12-14$ & $1956-66$ \\
\hline BHM.S2 & 0.93 & 1912 & 0.14 & 0.023 & 0.015 & 0.0085 & $6-8$ & $1971-86$ \\
\hline BHM.S3 & 0.43 & 1916 & 0.15 & 0.018 & 0.014 & 0.0047 & Double peak & -- \\
\hline BHM.S4a & 0.93 & 1903 & 0.20 & 0.024 & 0.017 & 0.0076 & $12-14$ & $1949-54$ \\
\hline Average & 0.88 & -- & 0.18 & 0.025 & 0.016 & 0.010 & -- & -- \\
\hline Standard deviation & 0.33 & -- & 0.03 & 0.007 & 0.002 & 0.007 & -- & -- \\
\hline
\end{tabular}

\section{Historical Changes in Estuary and Marsh Area}

The estuary has widened since the earliest aerial photos were taken in 1944. The widening is presumably related to erosion and collapse of channel banks. Widening of the estuary channel is especially apparent in the widest portions of the estuary and has resulted in an overall increase in the surface area of the estuary by about 7 percent from 1944 to 2010 (table 4). The change in estuary surface area (channel widening) has not been uniform over time. The channel widened by 5 percent between 1944 and 1955 and by an additional 2 percent from 1955 to 2010 . The reason for the apparent rapid rate of widening from 1944 to 1955 compared with later decades is not known. The bridge opening (tidal restriction) at the estuary outlet has not changed since the Tremont Road bridge was constructed in 1924 (Maine Department of Transportation, 2013).

Marsh surface area decreased by about 0.9 hectare (ha) or 3 percent from 1944 to 2010. The cause of this widening is not known but one possible explanation is that rising sea level may be causing channel and bank erosion resulting in widening. The fact that most of the widening apparently occurred from 1944 to 1955 may indicate that sea level rose above some threshold or tipping point at that time. The fact that the rate of widening at the estuary apparently decreased substantially after 1955, in spite of continuously rising sea levels since then, is not explained. Channel and bank erosion is a potential source of sediment that could be responsible for shoaling in the estuary. The fact that the turbidity data indicated that turbidity was substantially higher on the ebb tide compared with the flood tide would tend to rule out an oceanic source for this sediment. Similar estuary widening associated with rising sea level has been reported for another marsh complex in the Chesapeake Bay area in Maryland and Virginia (Kearney and others, 1988; Tiner and Bergquist, 2003).
Table 4. Historical changes in the Bass Harbor Marsh estuary, Mount Desert Island, Maine.

[Changes to the estuary channel and marsh areas are based on georeferenced aerial photographs. ha, hectares; NA, not available]

\begin{tabular}{cccccc}
\hline \multirow{2}{*}{ Year } & \multicolumn{2}{c}{ Estuary channel } & & \multicolumn{2}{c}{ Marsh surface } \\
\cline { 2 - 3 } \cline { 5 - 6 } & $\begin{array}{c}\text { Area, } \\
\text { in ha }\end{array}$ & $\begin{array}{c}\text { Cumulative } \\
\text { percentage change }\end{array}$ & & $\begin{array}{c}\text { Area, } \\
\text { in ha }\end{array}$ & $\begin{array}{c}\text { Cumulative } \\
\text { percentage change }\end{array}$ \\
\hline 1944 & 19.1 & NA & & 26.3 & NA \\
1955 & 20.1 & 5.03 & & 25.9 & -1.33 \\
1979 & 20.2 & 5.87 & 25.8 & -1.94 \\
1997 & 20.4 & 6.93 & 25.5 & -3.08 \\
2010 & 20.5 & 7.07 & 25.4 & -3.11 \\
\hline
\end{tabular}

\section{Projected Changes in Inundated Area and Estuary Volume}

Projected sea-level rise associated with ongoing climate warming will affect the area of land and hence the vegetation and marsh area within the estuary watershed that is inundated during the MHHW and MLLW. In this study area, where it is believed that isostatic adjustments due to uplift or subsidence are currently [2013] small compared with sea-level rise due to thermosteric effects and the melting of land-based ice (Kelley and others, 1996), the extent of changes in inundated area will depend on the relative rates of sea-level rise and marsh accretion, which in turn depend on sediment supply and vegetative growth (Kirwan and others, 2010). Marshes in the northeastern United States may be especially vulnerable because the supply of sediment has decreased 
since reforestation started about a century ago (Kirwan and others, 2011). The projected changes in the area that would be inundated and the increases in the volume of water in the estuary estimated in this report were simplistic in that they were calculated with the assumption that no sediment accretion occurs (that is, the estuary bottom and marsh surface elevations were fixed at their current [2013] levels).

Analysis of sediment chronologies, described in the ${ }^{210} \mathrm{~Pb}$ Chronology and Mass Accumulation Rates of Sediment and Organic Matter section, indicates that the elevation of the surface of the marsh appears to have nearly kept pace with the average sea-level rise of about $2 \mathrm{~mm} / \mathrm{yr}$ in this area during the latter half of the 20th century (National Oceanic and Atmospheric Administration, undated b). However, increases in the rate of sea-level rise in the Gulf of Maine since 1970 (Sallenger and others, 2012) and the projected acceleration in sea-level rise over the next century (by as much as a factor of 10; Parris and others, 2012) could substantially exceed the rate of marsh accretion in this tidally restricted estuary because of a lack of sediment supply. Therefore, under a worst case scenario of $200 \mathrm{~cm}$ of sea-level rise by 2100 (Parris and others, 2012), the observed sediment MARs at the surface of the marsh would not begin to keep up, rendering realistic the estimates of changes in inundation area and volume presented in this section. However, because sediment accretion will occur and more moderate rates of sea-level rise are likely than the worst-case scenario of $200 \mathrm{~cm}$, the potential increases in the area of inundation and the volume of water in the estuary presented in this section are probably overestimates and are shown for illustration rather than quantitative prediction.

The projected increases in inundated areas associated with 50,100 , and $200 \mathrm{~cm}$ of sea-level rise, which are assumed to translate into 30,60 , and $120 \mathrm{~cm}$ of average water level rise in the estuary at MHHW and MLLW, are listed in table 5. At MHHW, the inundated area increases from 25.7 ha at current [2013] conditions to 77.5 ha (or 200 percent) in association with a $100-\mathrm{cm}$ sea-level rise. This large increase occurs because the water level rises above the fringing marsh surface, flooding a substantial portion of the existing marsh at MHHW. If sea level were to rise by $200 \mathrm{~cm}$, then the inundated area at MHHW would increase by more than 400 percent, flooding the entire existing marsh and beyond, into peripheral forest areas that are not currently [2013] mapped as marsh. With a 200-cm sea-level rise, all the existing Spartina marsh adjacent to the estuary would be flooded at MLLW. In other words, with a 200-cm sea-level rise, the current [2013] marsh would be open water under almost all tidal conditions. Flooding of this extent currently occurs only under the very highest spring tides, but even with a more moderate $50-\mathrm{cm}$ sea-level rise, it would occur on average every other day. The uncertainty of these estimates is shown graphically as inundated areas at MHHW for a 200-cm sea-level rise as the 95 percent upper and lower confidence limits, using the reported lidar accuracy of $\pm 26 \mathrm{~cm}$ (fig. 4).

The volume of water in the estuary at MHHW, assuming no change in the existing bathymetry of the estuary or elevations in the fringing marsh, is projected to increase markedly with sea-level rise. The projected increases in estuary volume during MHHW and MLLW associated with 50,100 , and $200 \mathrm{~cm}$ of sea-level rise are listed in table 5 . At MHHW, the volume of water in the estuary is projected to increase from 176,000 cubic meters $\left(\mathrm{m}^{3}\right)$ under current [2013] conditions to $473,000 \mathrm{~m}^{3}$ (a 170 percent increase) in association with $100 \mathrm{~cm}$ of sea-level rise and to $1,130,000 \mathrm{~m}^{3}$ (a 540 percent increase) with $200 \mathrm{~cm}$ of sea-level rise. At MLLW, the volume of water in the estuary is projected to

Table 5. Projected changes in estuary area and in water volume associated with 50-, 100-, and 200-centimenter sea-level rise at mean higher high water and mean lower low water at Bass Harbor Marsh estuary, Mount Desert Island, Maine.

[NAVD 88, North American Vertical Datum of 1988; m, meters; ha, hectares; \%, percent; $\mathrm{m}^{3}$, cubic meters; NA, not available; cm, centimeters; SLR, sealevel rise]

\begin{tabular}{|c|c|c|c|c|c|}
\hline Condition & $\begin{array}{l}\text { NAVD } 88 \text { elevation, } \\
\text { in } \mathrm{m}\end{array}$ & $\begin{array}{l}\text { Area inundated, } \\
\text { in ha }\end{array}$ & $\begin{array}{c}\text { Increase in area, } \\
\text { in } \%\end{array}$ & $\begin{array}{l}\text { Estuary volume, } \\
\text { in } \mathbf{~ m}^{3}\end{array}$ & $\begin{array}{c}\text { Increase in volume, } \\
\text { in } \%\end{array}$ \\
\hline \multicolumn{6}{|c|}{ Mean higher high water } \\
\hline Current condition & 1.226 & 25.7 & NA & 176,000 & NA \\
\hline 50-cm SLR & 1.526 & 50.8 & 98 & 279,000 & 59 \\
\hline 100-cm SLR & 1.826 & 77.5 & 202 & 473,000 & 169 \\
\hline 200-cm SLR & 2.426 & 136 & 430 & $1,130,000$ & 543 \\
\hline \multicolumn{6}{|c|}{ Mean lower low water } \\
\hline Current condition & 0.727 & 21.6 & NA & 56,800 & NA \\
\hline 50-cm SLR & 1.027 & 24.1 & 12 & 126,000 & 122 \\
\hline 100-cm SLR & 1.327 & 26.7 & 24 & 203,000 & 257 \\
\hline 200-cm SLR & 1.927 & 89.7 & 315 & 559,000 & 834 \\
\hline
\end{tabular}




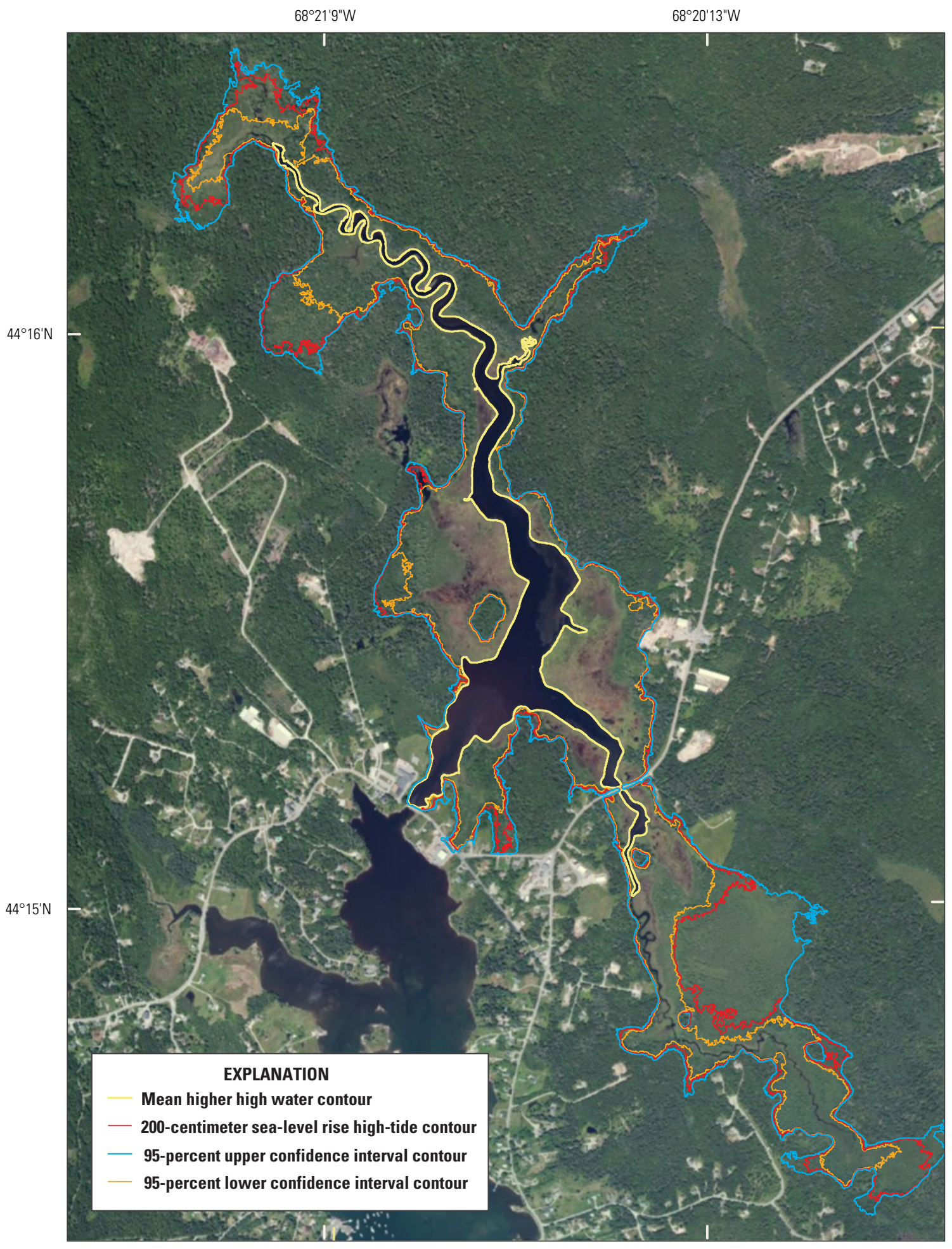

Satellite image from Maine Coastal Low Tide Ortho-rectified Digital Images, 2008 Maine Office of Geographic Information Systems

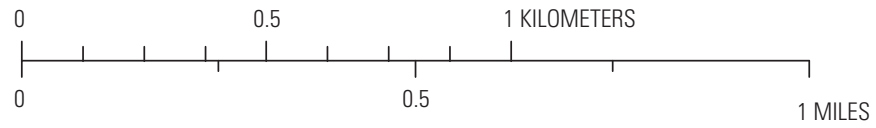

Figure 4. The predicted inundated areas within the Bass Harbor Marsh watershed, Mount Desert Island, Maine, mean higher high water (MHHW) following 200-cm sea-level rise with the 95-percent-upper- and lower-limit confidence bounds. The thick black line delineates the current [2013] channel boundary. Modified from Huntington and others (2014). 
increase from 56,800 $\mathrm{m}^{3}$ under current [2013] conditions to $203,000 \mathrm{~m}^{3}$ (a 260 percent increase) in association with $100 \mathrm{~cm}$ of sea-level rise and to $559,000 \mathrm{~m}^{3}$ (a 540 percent increase) with $200 \mathrm{~cm}$ of sea-level rise.

\section{Management Options to Minimize Nutrient Inputs to the Estuary}

Options by management to promote reduction of nutrient inputs to the estuary and nutrient residence times in the estuary, dilution of nutrient concentrations in the estuary, or flushing of nutrients out of the estuary more rapidly than with current activities could be effective in minimizing the growth of macroalgae in the estuary. The estuary is a dynamic system where the primary source of nutrients changes as inputs from watershed runoff change.

In a typical seasonal pattern, runoff and associated nutrient inputs increase from snowmelt in spring and after large storms; during these times, the watershed is the primary source of nutrients into the estuary. During summer and fall, which are usually periods of low streamflow, tidal inputs are the primary source of nutrients into the estuary. Given these relations, the strategies that could be employed to minimize nutrient inputs to the estuary would vary depending on the primary source of nutrients.

During periods when the watershed is the primary source of nutrients, reducing the height of the sill under the bridge would have the effect of increasing oceanic inputs. Increasing oceanic inputs would have the effect of increasing circulation and flushing within the estuary that would reduce the concentration of organic nitrogen and could increase flushing of algae from the estuary. During summer and fall, when the ocean is the primary source of nutrients, raising the height of the sill under the bridge would have the effect of decreasing oceanic nutrient inputs and thereby total nutrient inputs to the estuary during each tidal cycle.

If active management of nutrients were possible by regulating the size of the opening, then the volumes of oceanic inputs could be adjusted to be larger in the late spring and early summer to promote greater circulation and flushing of organic nitrogen and algae from the estuary. As the summer progressed, tributary inputs would decrease and oceanic nutrients would become proportionately more important than watershed-derived nutrients; to manage the amount of nutrients entering the estuary, the size of the estuary opening could be reduced gradually to decrease the amount of oceanic nutrients into the marsh. A similar strategy has been proposed for the regulation of tidal inputs using controlled gates as part of a comprehensive restoration plan for the Herring River Estuary in Wellfleet, Massachusetts, where one of the objectives is to improve water quality (Herring River Technical Committee, 2007).

Observations in 2008, 2009, 2011, and 2012 indicated that macroalgal growth is greatest from late May through
mid-July; this is consistent with what Kinney and Roman (1998) reported for the estuary. Given this temporal pattern, which may be related to nutrient inputs as well as water temperature (shown to increase to above $20^{\circ} \mathrm{C}$ in mid-May 2012; Huntington and others, 2014), the efforts to manage nutrient inputs for control of macroalgal growth would likely be most effective in early summer.

Ongoing trends towards surface air temperature warming in Maine (Keim and others, 2003; Hayhoe and others, 2007) and surface water temperature warming (Huntington and others, 2003; Juanes and others, 2004; Kaushal and others, 2010) may be exacerbating the growth of macroalgae (Rabalais and others, 2009; Kaushal and others, 2010). Kinney and Roman (1998) showed a positive relation between the biomass of the green macroalgae Ruppia maritima and water temperature in Bass Harbor Marsh. If the estuary were to become shallower because of sedimentation rates that exceeded the rate of sea-level rise, then the water temperature could increase even faster than the air temperature, resulting in further stimulation of macroalgal growth. Estuary management techniques that could increase the volume of the estuary, such as dredging, could be employed to increase water depth to mitigate warming that results from shoaling. Increasing the estuary volume in this way would also remove some of the particulate organic nitrogen that is likely mineralizing and contributing to nutrient enrichment.

\section{Limitations of this Study and Recommendations for Future Research}

This study quantified oceanic and terrestrial nutrient inputs to the estuary for two summers (May through September); nutrient inputs in early spring or in the fall were not considered. These two summers represented only a part of the variation in climatic and hydrologic conditions that could influence nutrient inputs to the estuary. Major storms can occur at any time of year, resulting in substantially larger nutrient inputs from terrestrial sources than were observed in this study. Nutrient concentrations in flood and especially ebb tides were not well mixed through the cross section; therefore, there was error associated with the assumption that the samples collected were truly representative of all the water flowing through the estuary outlet. Errors in nutrient concentrations result in uncertainty in the accuracy of the nutrient inputs and outputs estimated through the LOADEST regression. This study did not quantify nutrient release from or sequestration in sediments within the estuary or nutrient inputs to the estuary from groundwater.

Future research could help ANP resource managers to minimize eutrophication and macroalgal growth in the estuary. Implementation of a long-term monitoring program to track the extent of macroalgal growth and shoaling in the estuary to complement the monitoring of tributary nutrient concentrations by the NETN Program may be warranted. It would be 
useful to develop a hydrodynamic model to quantitatively estimate the effects of continuing sea-level rise and modifications to the estuary outlet opening on the level, residence time, tidal prism, and oceanic inputs of water to the estuary. Nutrient inputs to the estuary in groundwater remain a major uncertainty, but new tools offer the possibility of quantifying these inputs. Continuous measurements of tidal water flux and salinity can be used to estimate freshwater flux with high accuracy using the total exchange flow methodology described by MacCready (2011) and applied by Ganju and others (2012).

From the data on sediment and mass accumulation and the observed estuary channel widening we can deduce that the estuary and fringing marsh are undergoing geomorphic changes. It would be useful to monitor these changes in the future, particularly because the rates of change may respond to ongoing sea-level rise. Changes in channel bank erosion and sediment deposition could influence shoaling in the estuary and have the potential to be crucial to determining whether the elevation of the surface of the marsh can maintain its position relative to the increasing sea level. Continued monitoring of these processes would be especially useful because this information could help explain changes in elevation of the marsh surface that are being independently monitored with a surface elevation table (Cahoon and others, 2002) established in the marsh adjacent to the eastern bank of the estuary channel in 2010.

\section{Summary and Conclusions}

Eutrophication in the Bass Harbor Marsh Estuary on Mount Desert Island in Acadia National Park, Maine, is an ongoing problem manifested by recurring annual blooms of green macroalgae species, principally Enteromorpha prolifera and E. flexuosa; these blooms appear in spring and summer and are unsightly and impair the quality of this estuarine ecosystem. The U.S. Geological Survey and Acadia National Park have been collaborating for several years to better understand the factors related to this eutrophication problem with support from the U.S. Geological Survey and the National Park Service Water Quality Assessment and Monitoring Program. This report details the collection of hydrologic and waterquality data necessary to investigate the relative contribution of nutrients (nitrogen and phosphorus species) from oceanic (tidal) rather than terrestrial sources during summers 2011 and 2012. The report also describes nutrient budgets for this estuary, sedimentation chronologies for the estuary and fringing marsh, bathymetry in the estuary, historical changes (1944 to 2010) in surface area of the estuary, and changes in marsh area that would accompany sea-level rise.

The median concentrations of nitrate $\left(\mathrm{NO}_{3}\right)$, ammonium $\left(\mathrm{NH}_{4}\right)$, and total dissolved nitrogen (TDN) in the tributaries were generally lower than those observed on the flood tides, with the exception of $\mathrm{NO}_{3}$ in Marshall Brook (0.08 milligrams of nitrogen per liter (mg N/L)), which was about eight times higher than in the flood tide, and of $\mathrm{NH}_{4}$ in Adams Brook $(0.043 \mathrm{mg} \mathrm{N} / \mathrm{L})$, which was higher than in the flood tide. The concentrations of TDP were generally lower in the tributaries ( 0.005 to 0.013 milligrams of phosphorus per liter ( $\mathrm{mg} \mathrm{P} / \mathrm{L})$ ) than in the flood tide. The concentrations of $\mathrm{NO}_{3}$ and $\mathrm{NH}_{4}$ $(0.0097 \mathrm{mg} \mathrm{N} / \mathrm{L}$ and $0.025 \mathrm{mg} \mathrm{N} / \mathrm{L}$, respectively) and total dissolved phosphorus $(0.023 \mathrm{mg} \mathrm{P} / \mathrm{L})$ were approximately 25 percent higher than in the ebb tide during 2011 and 2012, indicating net assimilation of these nutrients in the estuary.

For summers 2011 and 2012, oceanic inputs of $\mathrm{NH}_{4}$ to the estuary were more than seven times larger than the combined inputs in watershed runoff and precipitation. In 2011, oceanic inputs of $\mathrm{NO}_{3}$ were about four times larger than watershed plus precipitation inputs, whereas in 2012, oceanic inputs were only slightly larger than watershed plus precipitation inputs. In 2011 oceanic inputs of dissolved organic nitrogen were larger than watershed inputs by a factor of 1.6. By contrast, in 2012 inputs of dissolved organic nitrogen in watershed runoff were much larger than oceanic inputs by a factor of 3.6. For the 2011 and 2012 seasons, oceanic inputs of TDN to the estuary were more than seven times larger than inputs in watershed runoff. From the nutrient budgets determined for the estuary it is evident that oceanic sources of $\mathrm{NH}_{4}, \mathrm{NO}_{3}$, and TDN are an important part of the supply of nutrients that are available for the growth of macroalgae in the estuary.

Continuously recorded turbidity measurements at the estuary outlet during parts of July, August, and September 2012 showed a consistent pattern whereby turbidity was lowest on the flood tide, increased during the ebb tide, and reached a maximum at the end of the ebb tide. This pattern indicated that the ocean was probably not a net source of sediment to the estuary.

Isotopic analysis of sediment cores from the estuary indicated a variable mass accumulation rate over time. Mass accumulation rate was lowest before 1930 (0.02 to 0.03 gram per square centimeter per year $\left.\left(\mathrm{g} / \mathrm{cm}^{2} / \mathrm{yr}\right)\right)$, increased somewhat from 1930 to 1960 , then more than doubled from 1960 to 1980 to 0.07 to $0.09 \mathrm{~g} / \mathrm{cm}^{2} / \mathrm{yr}$, and was in the range of 0.09 to $0.11 \mathrm{~g} / \mathrm{cm}^{2} / \mathrm{yr}$ after 1980 . The mass accumulation rates for the marsh that fringes the estuary showed rates of 0.018 to $0.036 \mathrm{~g} / \mathrm{cm}^{2} / \mathrm{yr}$ from the early $1900 \mathrm{~s}$ to 2011 . The average marsh accretion rate over this same period was 0.18 centimeter per year, indicating that the marsh surface had nearly kept up with the rate of sea-level rise in this area of 0.22 millimeter per year.

Analysis of georeferenced historical aerial photography indicated that the estuary has widened since the earliest available photograph in 1944. The area of the estuary widened by about 5 percent between 1944 and 1955 and by an additional 2 percent from 1955 to 2010 . The fringing marsh surface area decreased by 0.9 hectare or 3 percent from 1944 to 2010 . The erosion of the channel banks may be the source of sediment that could explain the mass accumulation rates in the estuary and shoaling in the estuary.

Projected future sea-level rise will likely result in an increase in the inundated area within the Bass Harbor Marsh 
watershed. A sea-level rise of 100 centimeters $(\mathrm{cm})$ would result in a 200 percent increase in inundated area at mean higher high water. A sea-level rise of $200 \mathrm{~cm}$ would result in a 300 percent increase in inundated area at mean lower low water, indicating that the entire marsh as it is currently [2013] would be inundated under almost all tidal conditions. These sea-level rise conditions would also result in large increases in the volume of water in the estuary.

The data in this report provide resource managers at Acadia National Park with a baseline that can be used to evaluate future conditions within the estuary. Climate change, sealevel rise, and land-use change within the estuary's watershed may influence nutrient dynamics, sedimentation, and eutrophication; these potential effects can be studied in relation to the baseline data provided. Structural changes to the bridge opening over a sill that controls oceanic inputs by restricting the duration of the flood tide could potentially alter oceanic nutrient inputs and residence times for watershed-derived and oceanic nutrients in the estuary. Ongoing sea-level rise is likely increasing oceanic nutrients and their residence times in the estuary on the one hand and decreasing the residence time of watershed-derived nutrients on the other.

\section{References Cited}

Appleby, P.G., and Oldfield, Frank, 1992, Application of ${ }^{210} \mathrm{~Pb}$ to sedimentation studies, chap. 21 of Ivanovich, M., and Harmon, R.S., ed., Uranium-series disequilibriumApplication to earth, marine, and environmental sciences (2d ed.): Oxford, Clarendon Press, p. 731-778.

Bricker, S.B., Clement, C.G., Pirhalla, D.E., Orlando, S.P., and Farrow, D.R.G., 1999, National estuarine eutrophication assessment-Effects of nutrient enrichment in the nation's estuaries: Silver Spring, Md., National Oceanic and Atmospheric Administration, 71 p. (Also available at http://ian.umces.edu/neea/pdfs/eutro_report.pdf.)

Cahoon, D.R., Lynch, J.C., Perez, B.C., Segura, Bradley, Holland, R.D., Stelly, Carol, Stephenson, Gary, and Hensel, Philippe, 2002, High precision measurements of wetland sediment elevation-II. The rod surface elevation table: Journal of Sedimentary Research, v. 72, no. 5, p. 734-739.

Culbertson, C.W., Huntington, T.G., and Caldwell, J.M., 2007, Nutrient enrichment in estuaries from discharge of shallow ground water, Mt. Desert Island, Maine: U.S. Geological Survey Scientific Investigations Report 2007-5188, 34 p., accessed April 7, 2010, at http:/pubs.usgs.gov/ sir/2007/5188/.
Doering, P.H., Roman, C.T., Beatty, L.L., Keller, A.A., and Oviatt, C.A., 1995, Water quality and habitat evaluation of Bass Harbor Marsh, Acadia National Park, Maine: National Park Service Technical Report NPS/NESORNR/NRTR/ 95-31, 148 p. plus appendixes. (Also available at https://archive.org/details/waterqualityhabi00doer.)

Farris, C.N., and Oviatt, C.A., 1999, Changes in metabolic rates under fluctuating salinity regimes for two subtidal estuarine habitats: Estuaries, v. 22, no. 1, p. 126-137.

Ganju, N.K., Hayn, Melanie, Chen, Shih-Nan, Howarth, R.W., Dickhudt, P.J., Aretxabaleta, A.L., and Marino, Roxanne, 2012, Tidal and groundwater fluxes to a shallow, microtidal estuary-Constraining inputs through field observations and hydrodynamic modeling: Estuaries and Coasts, v. 35, no. 5, p. 1285-1298.

Gesch, D.B., Gutierrez, B.T., and Gill, S.K., 2009, Coastal elevations, chap. 2 of Titus, J.G., coord., Coastal sensitivity to sea level rise-A focus on the mid-Atlantic region: U.S. Climate Change Science Program Synthesis and Assessment

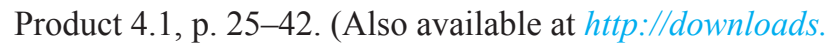
globalchange.gov/sap/sap4-1/sap4-1-final-report-all.pdf.)

Glibert, P.M., Boyer, J.M., Heil, C.A., Madden, C.J., Sturgis, Brian, and Wazniak, C.E., 2010, Blooms in lagoons different from those of river-dominated estuaries, in Kennish, M.J., and Pearl, H.W., eds., Coastal lagoons - Critical habitats of environmental change: Boca Raton, Fla., CRC Press, p. 91-113.

Glibert, P.M., Kelly, Vincent, Alexander, Jeffrey, Codispoti, L.A., Boicourt, W.C., Trice, T.M., and Michael, Bruce, 2008, In situ nutrient monitoring-A tool for capturing nutrient variability and the antecedent conditions that support algal blooms: Harmful Algae, v. 8, no. 1, p. 175-181.

Hargis, T.G., and Twilley, R.R., 1994, Improved coring device for measuring soil bulk density in a Louisiana deltaic marsh: Journal of Sedimentary Research: Sedimentary Petrology and Processes, v. 64A, no. 3, p. 681-683.

Hayhoe, Katharine, Wake, C.P., Huntington, T.G., Luo, Lifeng, Schwartz, M.D., Sheffield, Justin, Wood, E.F., Anderson, Bruce, Bradbury, J.A., DeGaetano, A.T., and Wolfe, David, 2007, Past and future changes in climate and hydrological indicators in the U.S. northeast: Climate Dynamics, v. 28, no. 4 , p. 381-407.

Herring River Technical Committee, 2007, Herring River tidal restoration project - Conceptual restoration plan; submitted to the Towns of Wellfleet and Truro and the Cape Cod National Seashore: Herring River Technical Committee, 136 p., accessed March 29, 2014, at http://www.nps.gov/ caco/naturescience/herring-river-conceptual-restorationplan.htm. 
Hirsch, R.M., 1982, A comparison of four streamflow record extension techniques: Water Resources Research, v. 18, no. 4 , p. 1081-1088.

Howarth, R.W., 2008, Coastal nitrogen pollution-A review of sources and trends globally and regionally: Harmful Algae, v. 8 , no. 1 , p. 14-20.

Huntington, T.G., Culbertson, C.W., and Duff, J.H., 2012, Ambient and potential denitrification rates in marsh soils of Northeast Creek and Bass Harbor Marsh watersheds, Mount Desert Island, Maine: U.S. Geological Survey Scientific Investigations Report 2012-5166, 40 p., accessed April 7, 2013, at http://pubs.usgs.gov/sir/2012/5166/.

Huntington, T.G., Culbertson, C.W., Fuller, Christopher, Glibert, Patricia, and Sturtevant, Luke, 2014, Nutrient budgets, marsh inundation under sea-level rise scenarios, and sediment chronologies for the Bass Harbor Marsh estuary at Acadia National Park: U.S. Geological Survey OpenFile Report 2014-1031, 108 p., http://dx.doi.org/10.3133/ ofr 20141031.

Huntington, T.G., Hodgkins, G.A., and Dudley, R.W., 2003, Historical trend in river ice thickness and coherence in hydroclimatological trends in Maine: Climatic Change, v. 61 , nos. $1-2$, p. 217-236.

Juanes, Francis, Gephard, Stephen, and Beland, K.F., 2004, Long-term changes in migration timing of adult Atlantic salmon (Salmo salar) at the southern edge of the species distribution: Canadian Journal of Fisheries and Aquatic Sciences, v. 61, no. 12, p. 2392-2400.

Kahl, J.S., Manski, David, Flora, Mark, and Houtman, Nick, eds., 2000, Water resources management plan: National Park Service, [variously paged], http://www.nature.nps.gov/ water/planning/management_plans/acadia_press.pdf.

Kaushal, S.S., Likens, G.E., Jaworski, N.A., Pace, M.L., Sides, A.M., Seekell, David, Belt, K.T., Secor, D.H., and Wingate, R.L., 2010, Rising stream and river temperatures in the United States: Frontiers in Ecology and the Environment, v. 8, no. 9, p. 461-466.

Kearney, M.S., Grace, R.E., and Stevenson, J.C., 1988, Marsh loss in Nanticoke estuary, Chesapeake Bay: The Geographical Review, v. 78, no. 2, p. 205-220.

Keim, B.D., Wilson, A.M., Wake, C.P., and Huntington, T.G., 2003, Are there spurious temperature trends in the United States climate division database?: Geophysical Research Letters, v. 30, no. 7, 1404, p. 57-1-57-4, accessed April 7, 2010, at http://dx.doi.org/10.1029/2002GL016295.
Kelley, J.T., Dickson, S.M., and Belknap, Daniel, 1996, Maine's history of sea-level changes: Maine Geological Survey, 16 p., accessed June 4, 2013, at http://maine.gov/ doc/nrimc/mgs/explore/marine/facts/sealevel.htm. Document moved, available at http://www.maine.gov/dacf/mgs/ explore/marine/facts/sealevel.pdf at time of publication.]

Kinney, E.H., and Roman, C.T., 1998, Response of primary producers to nutrient enrichment in a shallow estuary: Marine Ecology Progress Series, v. 163, p. 89-98.

Kirwan, M.L., Guntenspergen, G.R., D’Alpaos, Andrea, Morris, J.T., Mudd, S.M., and Temmerman, Stijn, 2010, Limits on the adaptability of coastal marshes to rising sea level: Geophysical Research Letters, v. 37, no. 23, L23401, 5 p., accessed June 15, 2012, at http://dx.doi. org/10.1029/2010GL045489.

Kirwan, M.L., Murray, A.B., Donnelly, J.P., and Corbett, D.R., 2011, Rapid wetland expansion during European settlement and its implication for marsh survival under modern sediment delivery rates: Geology, v. 39, no. 5, p. 507-510.

Levesque, V.A., and Oberg, K.A., 2012, Computing discharge using the index velocity method: U.S. Geological Survey Techniques and Methods, book 3, chap. A23, 148 p. (Also available at http://pubs.usgs.gov/tm/3a23/.)

Lucas, L.V., and Cloern, J.E., 2002, Effects of tidal shallowing and deepening on phytoplankton production dynamicsA modeling study: Estuaries and Coasts, v. 25, no. 4A, p. 497-507.

MacCready, Parker, 2011, Calculating estuarine exchange flow using isohaline coordinates: Journal of Physical Oceanography, v. 4, no. 6, p. 1116-1124.

Maine Department of Transportation, 2013, Structures in the municipality of Southwest Harbor: Maine Department of Transportation, 5 p., accessed January 5, 2014, at http://www.maine.gov/mdot/publicbridges/documents/ Tremont.pdf.

Microsoft Bing Maps, 2010, Bass Harbor Marsh estuary channel and fringing marsh [aerial view for 44 $15^{\prime} 27.45^{\prime \prime}$ N latitude, -68²0'39.73" W longitude]: Microsoft Bing, accessed January 7, 2013, at http://www.bing.com/maps/.

Mitchell, B.R., Shriver, Greg, Dieffenbach, Fred, Moore, Theresa, Faber-Langendoen, Don, Tierney, Geri, Lombard, Pam, and Gibbs, James, 2006, Northeast temperate network vital signs monitoring plan: National Park Service Technical Report NPS/NER/NRTR-2006/059, 131 p. (Also available at https://science.nature.nps.gov/im/units/netn/downloads/ NETN_MonitoringPlan_VitalSign_Compress.pdf.) 
National Atmospheric Deposition Program, [undated], Daily precipitation data for Acadia National Park, Mount Desert Island, Maine: National Atmospheric Deposition Program database, accessed May 7, 2013, at http://nadp.sws.uiuc. edu/data/ntn/.

National Oceanic and Atmospheric Administration, [undated] a, Tidal data for Frenchman's Bay, Bar Harbor, Maine: National Oceanic and Atmospheric Administration database, accessed December 20, 2012, at http://tidesandcurrents. noaa.gov/.

National Oceanic and Atmospheric Administration, [undated] b, Sea level trends data for Bar Harbor, Maine: National Oceanic and Atmospheric Administration database, accessed May 7, 2013, at http://www.tidesandcurrents.noaa. gov/sltrends.

National Research Council, 2000, Clean coastal watersUnderstanding and reducing the effects of nutrient pollution: Washington, D.C., National Academies Press, 428 p.

Neckles, H.A., Kopp, B.S., Nielsen, M.G., and Guntenspergen, G.R., 2003, Autotrophic responses to nutrient loadings in a Ruppia dominated estuary - Current status and future projections: Biennial Meeting of the Estuarine Research Federation, 17, September 14-18, 2003, Seattle, Wash., abstract, $1 \mathrm{p}$.

Nielsen, M.G., and Dudley, R.W., 2013, Estimates of future inundation of salt marshes in response to sea-level rise in and around Acadia National Park, Maine: U.S. Geological Survey Scientific Investigations Report 2012-5290, 20 p., accessed December 19, 2013, at http://pubs.usgs.gov/ sir/2012/5290/.

Nielsen, M.G., and Kahl, J.S., 2007, Nutrient export from watersheds on Mt. Desert Island, Maine, as a function of land use and fire history: Environmental Monitoring and Assessment, v. 126, nos. 1-3, p. 81-96.

Nixon, S.W., 1995, Coastal marine eutrophication-A definition, social causes, and future concerns: Ophelia, v. 41, no. 1, p. 199-219.

Parris, Adam, Bromirski, Peter, Burkett, Virginia, Cayan, Dan, Culver, Mary, Hall, John, Horton, Radley, Knuuti, Kevin, Moss, Richard, Obeysekera, Jayantha, Sallenger, Abby, and Weiss, Jeremy, 2012, Global sea level rise scenarios for the United States national climate assessment: National Oceanic and Atmospheric Administration Technical Memorandum OAR CPO-1, 29 p. (Also available at http://cpo.noaa.gov/ sites/cpo/Reports/2012/NOAA_SLR_r3.pdf.)

Patterson, W.A., III, Saunders, K.E., and Horton, L.J.,1983, Fire regimes of the coastal Maine forests of Acadia National Park: National Park Service Report OSS 83-3, 259 p. (Also available at $h$ ttps://archive.org/details/ fireregimesofcoa00patt.)
Rabalais, N.N., Turner, R.E., Díaz, R.J., and Justić, Dubravko, 2009, Global change and eutrophication of coastal waters: ICES Journal of Marine Science, v. 66, no. 7, p. 1528-1537.

Runkel, R.L., Crawford, C.G., and Cohn, T.A., 2004, Load estimator (LOADEST) - A Fortran program for estimating constituent loads in streams and rivers: U.S. Geological Survey Techniques and Methods, book 4, chap. A5, 69 p., accessed May 3, 2012, at http://pubs.usgs.gov/tm/2005/ tm $4 A 5 /$.

Sallenger, A.H., Jr., Doran, K.S., and Howd, P.A., 2012, Hotspot of accelerated sea-level rise on the Atlantic coast of North America: Nature Climate Change, v. 2, p. 884-888.

Tiner, R.W., and Bergquist, H.C., 2003, Historical analysis of wetlands and their functions for the Nanticoke River watershed-A comparison between pre-settlement and 1998 conditions: U.S. Fish and Wildlife Service technical report, 41 p. plus appendixes and maps. (Also available at http://www.fws.gov/northeast/EcologicalServices/pdf/ wetlands/Nanticoke04.pdf.)

Tobias, Craig, and Neubauer, S.C., 2009, Salt marsh biogeochemistry-An overview, chap. 16 of Perillo, G.M.E., Wolanski, Eric, Cahoon, D.R., and Brinson, M.M., eds., Coastal wetlands-An integrated ecosystem approach: Elsevier, p. 445-492. (Also available at http://links. baruch.sc.edu/faculty/Neubauer/Publications/Tobias\%20 Neubauer\%202009.pdf.)

Turnipseed, D.P., and Sauer, V.B., 2010, Discharge measurements at gaging stations: U.S. Geological Survey Techniques and Methods, book 3, chap. A8, 87 p. (Also available at http://pubs.usgs.gov/tm/tm3-a8/.)

U.S. Environmental Protection Agency, 2013, Level III ecoregions of the conterminous United States: U.S. Environmental Protection Agency, scale 1:7,500,000, accessed February 7, 2014, at $h t t p: / / w w w . e p a . g o v / w e d /$ pages/ecoregions/level_iii_iv.htm.

U.S. Geological Survey, [undated]a, USGS 01022840 Otter Creek near Bar Harbor, Maine-Surface water records for discharge of Otter Creek near Bar Harbor, Maine (USGS streamgaging station 01022840): U.S. Geological Survey National Water Information System, accessed March 27, 2013, at http://nwis.waterdata.usgs.gov/me/nwis/ uv/? site_no=01022840\&agency_cd=USGS\&amp;referred_ module $=$ sw.

U.S. Geological Survey, [undated]b, USGS 01022888 Adams Brook near Tremont, Maine - Water quality samples (USGS water quality sampling station 01022888): U.S. Geological Survey National Water Information System, accessed March 27, 2013, at http://nwis.waterdata.usgs.gov/nwis/ inventory/? site_no $=01022888$. 
U.S. Geological Survey, [undated]c, USGS 01022895 Heath Brook near Tremont, Maine-Water quality samples (USGS water quality sampling station 01022895): U.S. Geological Survey National Water Information System, accessed March 27, 2013, at http://nwis.waterdata.usgs.gov/nwis/ inventory/?site_no $=01022895$.

U.S. Geological Survey, [undated]d, USGS 01022892 Lurvey Brook near Southwest Harbor, Maine-Water quality samples (USGS water quality sampling station 01022892): U.S. Geological Survey National Water Information System, accessed March 27, 2013, at http://nwis.waterdata.usgs.gov/ nwis/inventory/?site_no $=01022892$.

U.S. Geological Survey, [undated]e, USGS 01022890 Marshall Brook near Southwest Harbor, Maine-Water quality samples (USGS water quality sampling station 01022890): U.S. Geological Survey National Water Information System, accessed March 27, 2013, at http://nwis.waterdata. usgs.gov/nwis/inventory/?site_no $=01022890$.

U.S. Geological Survey, [undated]f, USGS 010228955 Outlet Bass Hbr Marsh at Rt 102 at Tremont, MaineContinuous water quality data (USGS water quality sampling station 010228955): U.S. Geological Survey National Water Information System, accessed March 27, 2013, at http://waterdata.usgs.gov/me/nwis/uv/?site no $=010228955 \&$ agency_cd $=U S G S \&$ amp;referred_ module $=q w$.

U.S. Geological Survey, [undated]g, USGS 010228955 Outlet Bass Hbr Marsh at Rt 102 at Tremont, Maine-Water quality samples (USGS water quality sampling station 010228955): U.S. Geological Survey National Water Information System, accessed March 27, 2013, at http://nwis. waterdata.usgs.gov/nwis/inventory/?site_no $=010228955$.

Valiela, Ivan, Foreman, Kenneth, LaMontagne, Michael, Hersh, Douglas, Costa, Joseph, Peckol, Paulette, DeMeoAndreson, Barbara, D'Avanzo, Charlene, Babione, Michele, Sham, Chi-Ho, Brawley, John, and Lajtha, Kate, 1992, Couplings of watersheds and coastal waters-Sources and consequences of nutrient enrichment in Waquoit Bay, Massachusetts: Estuaries, v. 15, no. 4, p. 443-457. 

Prepared by the Pembroke Publishing Service Center

For more information concerning this report, contact:

Office Chief

Maine Office

New England Water Science Center

U.S. Geological Survey

196 Whitten Road

Augusta, ME 04330

dc_me@usgs.gov

or visit our Web site at:

http://me.water.usgs.gov 


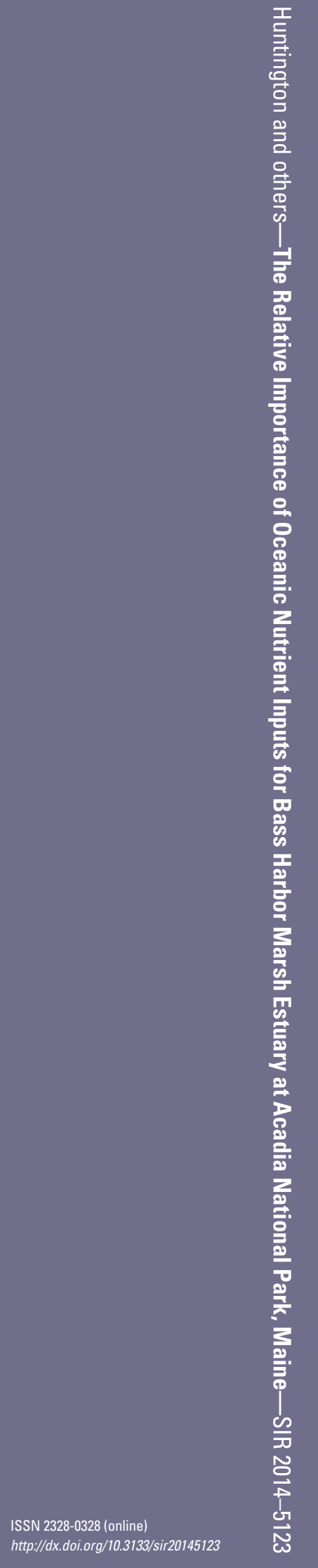

